\title{
WestVirginiaUniversity
}

THE RESEARCH REPOSITORY @ WVU

Graduate Theses, Dissertations, and Problem Reports

2018

\section{It Takes a Village: Collaborative Social Justice Through Choral Musicking}

Natalie Shaffer

Follow this and additional works at: https://researchrepository.wvu.edu/etd

\section{Recommended Citation}

Shaffer, Natalie, "It Takes a Village: Collaborative Social Justice Through Choral Musicking" (2018). Graduate Theses, Dissertations, and Problem Reports. 7249.

https://researchrepository.wvu.edu/etd/7249

This Thesis is protected by copyright and/or related rights. It has been brought to you by the The Research Repository @ WVU with permission from the rights-holder(s). You are free to use this Thesis in any way that is permitted by the copyright and related rights legislation that applies to your use. For other uses you must obtain permission from the rights-holder(s) directly, unless additional rights are indicated by a Creative Commons license in the record and/ or on the work itself. This Thesis has been accepted for inclusion in WVU Graduate Theses, Dissertations, and Problem Reports collection by an authorized administrator of The Research Repository @ WVU. For more information, please contact researchrepository@mail.wvu.edu. 


\title{
It Takes a Village: Collaborative Social Justice Through Choral Musicking
}

\author{
Natalie Shaffer
}

\begin{abstract}
Thesis submitted to the College of Creative Arts at West Virginia University in partial fulfillment of the requirements for the degree of

Master of Music in Music History.
\end{abstract}

Evan A. MacCarthy, Ph.D., chair

Travis Stimeling, Ph.D

David Taddie, Ph.D.

\author{
School of Music \\ Morgantown, WV \\ 2018
}

Keywords: Social Justice, Justice, Collaborative, Choir, Choral Music, Community, Narrative, Counter Narrative, Musicking, Memory, Memorying, Rememorying, Conductor, Chorus, Medical Ethnomusicology, Applied Ethnomusicology 


\section{ABSTRACT \\ It Takes a Village: Collaborative Social Justice Through Choral Musicking

\author{
Natalie Shaffer
}

Serious injustice and broken communities are not new developments in modern society. While lawmakers and religious leaders suggest fragments of possible solutions, an innovative possibility emerges from the work of musicians, specifically conductors in social justice choirs. These choirs provide participants the opportunity to foster cross cultural boundaries, define collective and personal identity, process trauma, and influence their larger community. As Julia Balén observes, singing with this type of choir is more than a pastime; it is a meaningful form of "protest through celebration." Gregory F. Barz holds a similar view which expands on the opportunity choral music making provides to foster social change thought the creation of a story contrasting with the existing cultural narrative. Without specifically identifying the current "master narrative," there is no chance of successfully constructing or presenting a new, and often more realistic, counter narrative that could bring about the change many hope to see in their communities.

My research intends to bring this practice of social justice exploration to conductors and music educators in traditional settings, including colleges, universities, K-12 schools, churches, and community music programs. These musicians may not desire to work solely with a homeless choir or an LGBTQI choir, but there are issues within their communities that affect them, their singers, and the families of those singers. By studying the methodology of existing groups and learning about an individual event, the Concept Freedom Summit at The Ohio State University held January 29-31, 2015, I provide useful and detailed information for leaders interested in spurring social change and increasing the sense of community within their own groups. Discussing the concepts of justice, social justice, and emerging sub-fields of ethnomusicology, namely medical ethnomusicology and applied ethnomusicology, advances knowledge that others can turn into understanding through their own experience. 
West Virginila Univaraity Electronic

Thesis and Dissertatlon Signature

$$
\text { Form }
$$

$\begin{array}{ll}\text { Student Name: } & \frac{\text { Shaffer }}{\text { (Last') }} \quad \text { Natal } \\ \text { Student ID*: } & 700271907\end{array}$

Non-Wvu Emall Account: shaffer_nneyahoo.com

Degree: M.M., Music History

Document Type:

$\begin{array}{ll}\mathrm{X} & \text { Master's Doctorate } \\ \mathrm{X} \quad \text { Thesis } & \text { Disgertation }\end{array}$

Document THe: Jt Takes a Village: Collaborative Social Justice through Choral Musicking

\section{Student Agreement:}

I hereby certify that, if appropriate, I have obtained and attached hereto a witten permission statement from the owners of each third party copyrighted malter to ba included in my thesis, dissertation, project repcrt, or othes research material, allowing distribution as specified upon deposit.

I hereby grant to Weat Virginia Univergity and its agents the non-excluslve llcense to archive and make accessible, under the condikions selected upon deposit, my above mentionea document in whole or in part in all forms of media, now or hareatter known. I retain owmership rights as specified in the WW copyright policy to the copyright of the abovernentioned document, I also retain the flight to use in future works (such as articles or books) atj of part of this abovementioned tocument.

\section{Review and Acceptance:}

The above mentioned document has been reviewed and accepted by the student's advisory committee. The undersigned agree to ablde by the statements above, and agree that thls Signature Form wpdates any and all prevlous Signature Forms stibmitted heretorore.

Signed:

Committee:
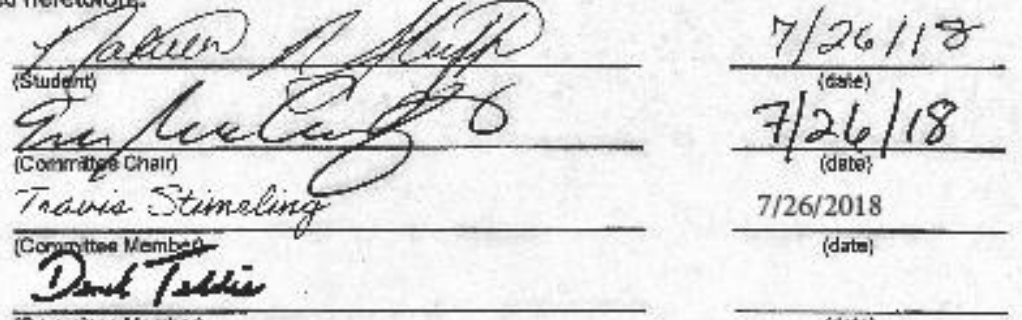

$7 / 26 / 2018$

(Carimitue Wertber)

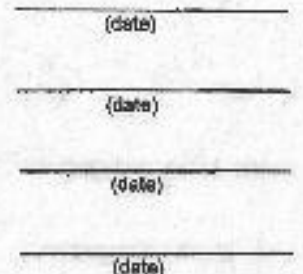

(Commithe Member) 


\section{Acknowledgments}

The journey through creating this document took many twists and turns and inspired many moments of frustration. I want to recognize the unwavering support of my parents Larry and Twila, as well as the calm reinforcement of my wonderful friend Marsha Brand along the way. I would like to acknowledge Dr. Kristina MacMullen for her willingness to participate in this project and facilitate communication with the members of The Ohio State Women's Glee Club. Finally, I need to express my gratitude toward Dr. Evan MacCarthy whose scholarship inspires me as much as his character. His patience and guidance were instrumental to the completion of this text.

Natalie Shaffer 


\section{Table of Contents}

Introduction: "You Really Think Music Can Change Things?" $\ldots \ldots \ldots \ldots \ldots \ldots \ldots \ldots \ldots \ldots$

Chapter 1. Justice as a Concept: The Good, The Bad, and The Healing ................... 8

Chapter 2. Justice as an Invitation: “Come Together, Right Now, Over Me.” .............. 25

Chapter 3. Justice as a Practice: Social Change through Musicking .................... 43

Chapter 4. Justice in Our Stories: Successful Counter Narratives ..................... 60

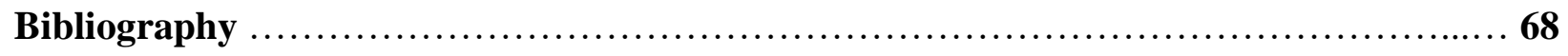




\section{Introduction \\ "You Really Think Music Can Change Things?"}

I came to this project unexpectedly and with less than perfect timing. As a second-year graduate student, I completed all coursework in a music history degree years ago and identified an interest in American music to be my field of study, specifically violence in American opera. I planned to use Carlisle Floyd and his operatic melodrama Susannah (1955) as the basis for my research. With the thesis document yet to be created, I accepted a music position in the public schools of West Virginia. During those years I found myself devoted to making inspired choral music with students at the "bad" middle school. These young people, most from low income households, many crushed by the effects of addiction around them, all wrestling with selfidentification, and some understandably angry, became not only exceptional choral musicians but advocates. They came to treat one another, their families, and the school community with compassion, often in difficult situations. Wanting to play an active role in creating change, they willingly performed pieces asking for validation and acceptance, including Andrea Ramsey's 2006 work Letter from a Girl to the World which includes an opportunity for the performers to voice their personal goals and aspirations during the final section. I discussed the concepts of fairness, equality, and justice with them. I worked with counselors to provide materials for support for those who were homeless, dealing with addiction and alcoholism themselves or in their family, and survivors of abuse. I sang challenging music and introduced them to many other cultures. I became active in local organizations focused on recovery, child advocacy, and local assistance. I did not write my thesis.

As time moved on I decided to pursue a graduate degree in choral conducting, the area where I felt I was making a difference. I began studies at the same institution as before and 
acknowledged that while I enjoyed learning about music history and ethnomusicology, the scholarship of violence in American opera seemed far removed and less practical a place to focus. I planned to just write the document since the research was done and finish with both degrees. Then in March of 2017, I attended the American Choral Directors Association National Conference in Minneapolis, Minnesota and had the pleasure of attending a session presented by Dr. Kristina MacMullen of The Ohio State University entitled “A Voice of Reason: Social Justice, the Greater Good, and Why We Sing." She shared her experience identifying an issue of social injustice in her community, human trafficking, and the steps she took to create a platform to educate and inspire others by creating a multi-media choral concert as part of a three-day summit hosted at her university. With one academic year remaining and many hours of reading and research already complete, I knew this session was what I wanted to write about, and perhaps more importantly, that this is what I wanted to do.

After informing my thesis chairperson of the presentation's effect on me and admitting the extreme level of "this is a bad idea" present in my current course of action, I changed my thesis topic. While the common threads of America, music, and violence remained in some form, the focus of research shifted dramatically. I began contemplating applied ethnomusicology and social justice. I listened to recordings from existing social justice choirs, studied programming choices, and read interviews with participants. I came across references discussing the psychological benefits of community music making and successful validation of self and group identity of choir members. I considered the healing opportunities of such groups after learning about medical ethnomusicology and this course of action seemed to be a perfect fit.

As I shared this interest with the advisor of my conducting degree who suggested I take over her role as artistic director with a local homeless choir. Now once a week I find myself in a 
dark old church with Gothic architecture and no cushions on the seats singing with a group of homeless men and women. There is a core group of six or seven individuals that are generally present, but outside them attendance is random, ranging from twenty-five to five. I suggest songs and so do they. Recently we wrote a song together that has since become the theme song of the group; it is called Let's Take This One Day at a Time. As we continue to work together and begin to trust one another, I learn their stories. As I listened, I came to realize addiction was at center of nearly every narrative. The topic of addiction in association with the state of West Virginia is generally well-known due to national media coverage and documentaries like Netflix's 2017 Heroin(e). It became exceedingly clear that this issue of social justice, present in both my previous middle school students and now in my adult community choir, would become the focus of my work in collaborative social justice through choral musicking. I knew what I wanted to do but I did not yet know how to do it. That realization became the driving force behind the methodology of this research document.

My goal is to create a general outline to address issues of social justice through choral music. To create this "procedure" I examine established social justice choirs/choruses and their ability to effect social change and raise awareness. Discussion of rehearsal techniques, programming selections, and community involvement are also of note as I gather resources. The concepts identified by primary researchers for this text center on the idea of an existing narrative and a created counternarrative. While many situational and cultural elements of the groups selected to examine differ drastically, the practice of creating a counternarrative and sending it out into the community positioned for acceptance explains a major function of the choir in this process. I also accept the reality that many choir directors do not desire to work solely with a social justice choir but may find the experience of Dr. MacMullen and the summit at The Ohio 
State University extremely helpful. I chose that specific event to provide a case study into collaborative social justice and choral music and propose one-on-one interviews following a semi-structured format as the primary source of data collection. Specifically, the account of the choir director Dr. Kristina MacMullen and her process of identifying and educating herself on an issue of social justice in her community provides applicable information to those musicians interested in social justice work.

Serious injustice and broken communities are not new developments in modern society. However, the recent surge of political activism, coupled with the prevalence of social media use, keep discussion of social justice issues in the forefront of news cycles and commonplace conversations alike. While lawmakers and religious leaders suggest fragments of possible solutions, an innovative possibility emerges from the work of musicians, specifically conductors in social justice choirs. These choirs provide participants the opportunity to cross cultural boundaries, define collective and personal identity, process trauma, and influence their larger community. As Julia Balén observes, singing with this type of choir is more than a pastime; it is a meaningful form of "protest through celebration." Gregory F. Barz holds a similar view which expands on the opportunity choral music making provides to create and offer a counternarrative to the existing cultural story. ${ }^{2}$ Both agree that without specifically identifying the current "master narrative," to use Balén's term, there is no chance of successfully constructing or presenting a new, and often more realistic, story that could bring about the change many hope to see in their communities.

\footnotetext{
${ }^{1}$ Julia Balén, A Queerly Joyful Noise: Choral Musicking for Social Justice (New Brunswick: Rutgers University Press, 2017), iv.

${ }^{2}$ Gregory Barz, Singing for Life: HIV/AIDS and Music in Uganda (London: Routledge, 2014).
} 
The opening chapter provides the ground level information for the argument that choral musicking can serve as a vehicle for collaborative social justice. To begin examining such issues, a clear definition of justice and social justice are needed, along with resources researching its connection to choral music. The first chapter begins with background information defining justice and social justice and quickly introduces the importance of critical theory in this evaluation. With information brought forth from sociologist and music educator Estelle Jorgensen, the consideration of cultural institutions and societal norms in the creation of "right and wrong" and "good and bad" assist in identifying the benefits of upholding structures that create and perpetuate social inequity. ${ }^{3}$ The knowledge of who profits, and how, provides important understanding to those individuals creating strategic approaches to social justice and crafting counternarratives to existing cultural norms.

Chapter one also introduces the practices of applied ethnomusicology and medical ethnomusicology as they pertain to the creation of approach and methodology to follow in the research document. It includes the work of American folklore ethnologist Elaine Lawless related to applied reflexive ethnography, American ethnomusicologist Gregory Barz and his multiple texts concerning applied ethnomusicology and medical ethnomusicology, and American ethnomusicologist Benjamin Koen’s insights into medical ethnomusicology. Discussion of methodology and the connection between pursuit of social justice through choral music and ethnomusicology are addressed through examination of literature. It culminates in discussion of the idea of collaborative social justice and its efficiency to promote social change.

This second chapter examines existing social justice choirs using characteristic components of applied and medical ethnomusicology and explores the process of 'musicking,' as

\footnotetext{
3 Jorgensen, "Intersecting Social Justices and Music Education," in The Oxford Handbook of Social Justice in Music Education, edited by Paul Woodford (New York: Oxford University Press, 2015).
} 
coined by Christopher Small. The methodology for discussion of their function and accomplishment within their respective communities is adapted from the primary goals written by Gregory Barz in relation to his work with the social justice issue of HIV/AIDS in Uganda. Of those selected for examination, the musical groups from Uganda provide an example of musicking's role with a traditional medical disease, while Julia Balén explores the musicking of choruses devoted to the cultural disease related to many ways to HIV/AIDS, the LGBTQIA community. Comparison of Barz's work centered on the practice re-memorying ideas through existing social structure and cultural norms with Balén's process of counterstorying by creating and circulating a counternarrative as a model for examining choral social justice events, establishes a successful process for musicking and social change.

The third chapter provides a case study of a collegiate choir, not identified as a social justice choir, and their immediate community. Dr. Kristina MacMullen and The Ohio University Women's Glee Ensemble provide the cornerstone of a three-day summit on campus at The Ohio State University called Concept Freedom with their choral concert. Data were gathered from interviews of the choral ensemble members, the director, and accompanist directly involved with the summit whose primary goal was to bring awareness to the subject of human trafficking and raise support for its survivors. These interviews are of a semi-structured nature with a basic fifteen item questionnaire and additional time for specific questions that arise during the initial section of the interview. Goals of this research are to identify ways in which participating in choral musicking at the summit resulted in healing, offered clearer definition of self-identity and group identity, and observe effects of the counternarrative provided by the summit in the community at The Ohio State University. 
The concluding chapter's goal is to provide a possible methodology to create a social justice event, using the Concept Freedom summit at The Ohio State University as a model. The idea that all conductors and music educators want to work with or form a social justice choir is not realistic, but the notion that many would like to use their platform to bring to light a specific issue in their community is. Through examination of theoretical approaches, discussion of innovative techniques, and personal interviews the reader of this research document should find the blueprint to creating a community conversation and social change through education, empowerment, and the process of choral musicking.

My research intends to bring this practice of social justice exploration to conductors and music educators in traditional settings, including colleges, universities, K-12 schools, churches, and community music programs. These musicians may not desire to work solely with a homeless choir or an LGBTQI choir, but there are issues within their communities that affect them, their singers, and the families of those singers. By studying the methodology of existing groups and learning about an individual event, the Concept Freedom Summit at The Ohio State University held January 29-31, 2015, I will provide useful and detailed information for leaders interested in spurring social change and increasing the sense of community within their own groups.

Discussing the concepts of justice, social justice, and emerging sub-fields of ethnomusicology, namely medical ethnomusicology and applied ethnomusicology, advances knowledge that others can turn into understanding through their own experience. 


\section{Chapter 1}

\section{Justice as a Concept: The Good, the Bad, and the Healing}

\section{The Function of Justice}

The written log of discussions, definitions, and situations of practice concerning justice dates back to antiquity. Scholarly men, philosophers of the age, wrote down their conversations with peers and students entertaining the ideas of exactly what justice was, how it was defined, and who defined it. Modern society's general conception that justice provides the fundamental basis for a humane and civil society is rooted in these ancient musings. ${ }^{1}$ Another facet of this long-standing justice discussion, that seems to be absent in many current conversations, is the acknowledgement that what is deemed just or righteous is based on specific behavior patterns that are defined by the ruling systems and institutions of the given society and considered normative. Estelle Jorgensen expands on this awareness while demonstrating how the music community can support the intersecting of social justice with music education. stating that "much depends on how evil and wrong doing are defined within the sponsoring groups, communities, and institutions of society." In other words, and through a lens of critical theory, the current master narrative of what is just versus what is evil is grossly influenced by the ruling institutions of society who commonly stand to benefit from the continuation of existing power structures in some manner. That master narrative, therefore, or the accepted truth behind it, of what is just and noble should be examined rather than complacently accepted. Understanding which actions

\footnotetext{
${ }^{1}$ Jorgensen, "Intersecting Social Justices and Music Education," in The Oxford Handbook of Social Justice in Music Education, edited by Paul Woodford (New York: Oxford University Press, 2015), 8. ${ }^{2}$ Jorgensen, 10.
} 
belong in those categories is perhaps less important than comprehending the rationale behind the creation of the categories.

For example, consider the English folklore legend of the outlaw activist Robin Hood. Were his actions considered "bad" simply because he was stealing, or was it because he was taking excess from the powerful members of society to provide necessities for the less worthy? Members of the royal government and church took money, personal items, and livestock for the societal elite, but were not viewed as thieves or punished; their actions stood to reinforce the existing power structure. Robin Hood's alleged actions stood to expose the inequities of the ruling government system, highlight possible corruption in the church, and provide the powerless a means to gain power of their own. Thus, one man is viewed a criminal, while the other is noble and loyal to the throne.

This pursuit of an authentic understanding of justice "emphasizes the worth, dignity, and preciousness of human beings while reinforcing a sense of self-respect and self-worth in those who pursue and receive it." ${ }^{3}$ The focus is on individuals and their intangible experiences. Lee Higgins reminds readers of a simple but helpful fact: justice is not the same as law. ${ }^{4}$ Perceiving law as simply enforcing justice removes the intrinsic value and benefits of the practice of justice itself. However, viewing laws as a tool of one of the earliest institutions, government, one becomes aware of their limited outcomes, short-sighted solutions to long term problems, and the ease with which they are manipulated to retain power structures. Higgins adds that "experienced as an invitation, justice is structured toward an unforeseeable future, calling us to always rethink

\footnotetext{
${ }^{3}$ Jorgensen, "Intersecting Social Justices and Music Education," 10.

${ }^{4}$ Higgins, "Hospitable Music Making: Community Music as a Site for Social Justice," in The Oxford Handbook of Social Justice in Music Education, edited by Paul Woodford (New York: Oxford University Press, 2015), 448.
} 
and reinvent the conditional forms suggested by the law." ${ }^{, 5}$ In his view, despite the inability to concretely understand justice or even accurately describe it, one should always find striving to achieve it, a worthwhile endeavor.

When considered as a subject never fully knowable but of immense value, "justice is inhabited by a memory of those who have died in its name, those who are, and who continue to be oppressed, as well as those who have been liberated under its call." ${ }^{\prime 6}$ In these memories lie a hopefulness of justice's purpose, power, and promise. It is with that optimism in mind that the working understanding of justice for this document can be stated as a hopeful enterprise where "humans who have a heart toward justice" consciously take an affirmative step toward another human being. ${ }^{7}$ Higgins discusses this process of "making promises to one another" in a chapter specifically dedicated to community music as a site for social justice, but his concept is just as applicable for choirs in universities, K-12 classrooms, churches, and other group settings. By experimenting with ways to express one's value to others and selecting pieces that explore topics of worth and relevance to the community, a group of choristers could become a vehicle for social justice.

\section{Functionalities of Social Justice}

“The pursuit of social justice presupposes an interest in creating or fostering a more humane society."8 Currently, the phrase "social justice" is a loaded phrase with preexisting ties for many. Presenting the idea of addressing a "social justice issue" or forming a "social justice

\footnotetext{
${ }^{5}$ Higgins, "Hospitable Music Making: Community Music as a Site for Social Justice," 448.

${ }^{6}$ Higgins, 449.

${ }^{7}$ Higgins, 448 .

${ }^{8}$ Woodford et al., The Oxford Handbook of Social Justice in Music Education, (New York: Oxford University Press, 2015), 3.
} 
choir" by using those exact terms may prove difficult as some members of the group could become immediately defensive or resistant. In search of a definition disconnected from those problematic connotations, consider the understanding that social justice is "social and economic equality and democracy," or the idea that true social justice would require all members of society have equal access to public goods, resources of institutions, and opportunities in life." ${ }^{\prime 9}$ Such inclusive principles would allow participation by any class or group of people in the decision making and control of society around them and, in theory, alleviate social injustice.

Two possible problems standing in the way of achieving justice are the society's "ingrained cultural and societal habits and norms, and the inability to empathize or imagine a more humane and just way." ${ }^{10}$ These habits and norms can range of large scale occurrences of inequality to every day practices. A specific example in the field of music education is the established constructivist theory of learning. The application of critical theory, with its roots in opposition and critique, to this teaching model results in appropriate and necessary discussions of social justice in music. The resultant proposed contrast challenges music educators and conductors to develop approaches based in "possibility, imagination, and relationality, rather than conformity to standardized practices and conventional ways of thinking." ${ }^{11}$ Examining the ethical and practical possibilities to approach music pedagogy as an enactive process allows conductors to utilize the full possibilities of music for increased human well-being. Taking stock and being willing to change programming and teaching styles can bring social justice into the musicking experience, but choral music directors inclined to pursue social justice will also need

\footnotetext{
${ }^{9}$ Guylaine Vaillancourt, "Music Therapy: A Community Approach to Social Justice," The Arts in Psychotherapy 39, no. 3 (July 2012): 174, http://www.sciencedirect.com/science/article/pii/S0197455611001328 (accessed October 25, 2017).

${ }^{10}$ Jorgensen, "Intersecting Social Justices and Music Education," 10.

${ }^{11}$ van der Schyff, Schiavio, and Elliott, "Critical Ontology for an Enactive Music Pedagogy."
} 
an ever-evolving understanding of the term itself, as well as the ability to identify the specific way another human being is not being treated as worthy. Without the capacity to relate the validity of the issue to the group, and particularly the members in question, a director may not be successful in this endeavor. To begin narrowing this broad understanding of social justice to a working definition for the sake of this research document, one can also consider the various functionalities of social justice.

\section{$\underline{\text { Distributive Justice }}$}

Returning to Jorgensen's work on intersecting social justices and music education provides a myriad of ways social justice may operate. Social justice as distributive justice occurs when the focus seems to be placed on ensuring the common good over the benefit of individuals. ${ }^{12}$ This type of social justice is often located in musical settings as directors strive to include everyone in music making and focus on what the group can accomplish through working together rather than as solo singers. A contrasting category, social justice as contributive music, is based on what the individual can give to the group. ${ }^{13}$ Despite being defined in opposite terms, social distributive and social contributive types of justice coexist in most music ensembles. While working together to accomplish the goal of a performance, distributive justice is at work as members often surrender free time, personal space, and mental energy to rehearse in an effective manner. Contributive justice occurs simultaneously with distributive justice in instrumental rehearsals as members play the instrument of their choice and skill set, regardless of any former gender association such as "only boys play the drums." Similarly, they coexist in

\footnotetext{
12 Jorgensen, "Intersecting Social Justices and Music Education," 11.

${ }^{13}$ Jorgensen, 13.
} 
choral ensembles as members sing parts historically associated with a specific gender, such as a group performing Renaissance motets and using high-voiced singers of any gender as sopranos.

\section{Commutative Justice}

Examining social justice as commutative justice is perhaps most successful when keeping in mind the understanding of justice being the conscious movement toward one another as fellow human beings. Jorgensen views commutative justice as the "contractual obligations that exist between individuals, groups, and society." 14 Her examples include the teacher who feels the need to honor their responsibility of meeting the rules and regulations laid out before them at the time of their hiring. Jorgensen quickly follows that, in turn, the public, politicians, and education policymakers should share a desire to uphold their responsibility to provide the conditions, supplies, and experiences needed for the aforementioned teachers to be successful. In this hypothetical situation, both groups take a step toward one another in a positive manner that keeps the focus on the subject at hand, education. Taking that step shows teachers giving value to the work of parents, school board members, and legislators through their deeds and the latter group reinforcing their views of teachers having worth through their participation and policy making.

Observing social justice functioning as commutative justice in a strictly choral setting looks slightly different than the teacher example, but the practice provides a wealth of understanding and possibility. Choir members have chosen, whether by participation in the audition process, in fulfillment of a requirement of their degree choice, or personal interest, to become an ensemble member. Choirs aim to create musical experiences for themselves and their audiences. Lastly, music, as with all art, is a direct reflection of the society around it. With these caveats in place it seems an appropriate prospect that choir members should honor the

\footnotetext{
${ }^{14}$ Jorgensen, "Intersecting Social Justices and Music Education," 13.
} 
responsibility of preparing and offering a true reflection of that society. That might include a popular Glee-style mashup of Bruno Mars favorites used to reflect the prominent use of sampling in popular music culture to create nostalgia, thus offering an escape from the stressors of present day life by experiencing positive emotion associated with the past. But it need also include examples like the simplistic yet powerful three-part treble writing of Kim Baryluk's 2012 work Warrior, with a text provided by a female survivor of domestic abuse, in a community with dangerously high mortality statistics for victims of domestic abuse. One end of the subject matter spectrum cannot exist without the other. Just as a concert programed completely with pop music leaves a deficit, so would a choir devoted solely to pieces centered on domestic violence. Positive and negative exists in society and both need to be reflected to retain the power of either.

Jennifer Miles expands on the notion that art reflects the culture around it with the statement that "Art simultaneously draws from culture and produces culture." 15 Members of the audience experiencing this musical reflection, receive the content from differing points of view, influenced from their life experience. The individuals in attendance fit into multiple categories of relation to both performers and their community at large. These roles may include close relations such as family members, friends, and neighbors as well as extended community relations like postal workers, ministers, police force, lawmakers, and the list could continue. The diversity of roles one identifies with affords numerous options to decide in what direction their step toward another human could take place. "Authors acknowledge the power of poetry (lyrics) to personalize struggles... and give a voice to sometimes impersonal discourses of oppression

\footnotetext{
${ }^{15}$ Jennifer Miles and Laura Dawson, “The Art of Social Justice," Humboldt Journal of Social Relations 34, (2012): 2, http://www.jstor.org/stable/humjsocrel.34. (accessed January 31, 2018).
} 
and injustice." ${ }^{\prime 16}$ Audience members may find themselves examining the personal effects of being shown the reality of daily life for many around them from which they may be removed.

Whether watching a concert or viewing a piece of art, the audience member's participation may position them to take a step toward another when the opportunity presents itself in the future. San Francisco artist Juana Alicia says that regardless of the topic of the piece, she is "working to bring the interior life of the community to the fabric of our architecture and environment, to promote a dialogue between members of diverse communities." ${ }^{" 17}$ Perhaps that dialogue takes the form of a conversation voicing concern with a neighbor from the household known for its loud fights, or a statement to a family member about why they support a new policy banning domestic abusers from purchasing firearms, or vote in support of a candidate who includes this topic as part of their platform. There may be no traditional dialogue but instead an internal one where the audience member reconsiders firing someone who called off from work only to return with visible bruises or evident emotional stress. Or they could simply acknowledge and validate the existence of the social issue. Each approach is a valid avenue to pursue justice in tangible ways in the immediate community of the audience member and exemplifies the structure of viewing social justice as commutative justice.

\section{Procedural Justice}

An additional function of social justice extremely applicable in a choral setting, is its manifestation as procedural justice. The idea being that value resides in the process more so than in the product and the general sense of fair play. ${ }^{18}$ As will be discussed in Chapter Three, the

\footnotetext{
${ }^{16}$ Miles and Dawson, "The Art of Social Justice," 2.

${ }^{17}$ Martinez, "The Art of Social Justice," Social Justice 34, no. 107 (2007): 10, http://www.jstor.org/stable/29768418 (accessed January 31, 2018).

${ }^{18}$ Jorgensen, "Intersecting Social Justices and Music Education," 13.
} 
women's vocal ensemble at the Ohio State University known as Women's Glee hoped to create a weekend long event, culminating in a choral concert, which would dramatically affect the community in Columbus, Ohio where the number of sex-trafficking victims is on a steady incline. While the performance (product) was quite successful in terms of choral music quality, the director reflects specifically on the importance of the process of preparing and rehearsing the music for herself, her choir members, and victims and survivors in the community. By setting aside rehearsal time and creating an appropriate environment for survivors to feel comfortable sharing their stories, the director and her choir members acknowledged the need for that opportunity and reinforced the esteem in which survivors would be held throughout the event.

\section{$\underline{\text { Poetic Justice }}$}

Jorgensen identifies nearly twenty social justice definitions, but the final two found most applicable to choral music making are social justice as poetic justice and restorative justice. The practice of choral musicking bringing about poetic justice will be explored in depth in chapter two as Jorgensen's explanation that this type of justice occurs when minorities are valued as part of the community and, as a result, all members of the group grow physically and spiritually from the experience. ${ }^{19}$ The San Francisco Gay Men's Chorus will provide a case study into the achievement of poetic justice through members of the minority striving to create art that accurately reflects their experience and their community. This poetic justice of music making also lies at the heart of Higgins' discussion of the 'hopefulness' of the work (social justice based choral musicking) and the outcome of making decisions from a place of inclusivity and diversity. ${ }^{20}$

\footnotetext{
${ }^{19}$ Jorgensen, "Intersecting Social Justices and Music Education," 15.

${ }^{20}$ Higgins, "Hospitable Music Making: Community Music as a Site for Social Justice," 448.
} 


\section{$\underline{\text { Restorative Justice }}$}

Finally, Jorgensen summarizes restorative justice as the process of correcting past inequities and states "traditional thought and practice concerning individuals and groups may need to be rethought and reworked in order to restore what has been lost to those who have been wronged." ${ }^{21}$ A timely example to explore this facet of justice and where intentions of rectifying past inequities fall short is the policy of "Affirmative Action." This process of reserving spots in college acceptance processes for people of color and requiring certain ratios of employee ethnicities, disabilities, and gender of employers during the hiring process exemplifies many concepts addressed in this discussion of justice. As an act of restorative justice, yes, the government and corporations were attempting to rectify injustices of the past. The reason this process falls short of its goal seems to be twofold. First, institutions attempted to use laws and policies to enforce justice. The result was a short-sighted and punitive solution to the larger problem of ingrained racism, ableism, and sexism in the society in question. The second issue is one of particular merit for conductors and music educators interested in "doing justice" in a truly helpful way: the problem of speaking for others.

Linda Alcoff clearly articulates the belief that "both the study of and the advocacy for the oppressed must come to be done principally by the oppressed themselves." 22 While the nonoppressed members of society hold the privilege and status to call attention and begin correcting injustice, they likely do not have the appropriate experience to evaluate if the remedies enacted are successful. The key words from that statement being "come to be" and "principally" imply

\footnotetext{
${ }^{21}$ Jorgensen, "Intersecting Social Justices and Music Education," 14.

${ }^{22}$ Linda Alcoff, "The Problem of Speaking for Others," Cultural Critique, no. 20 (Winter 1991-1992): 8 http://www.jstor.org/stable/1354221 (accessed November 7, 2017).
} 
that at some point control over this process of finding justice needs to be relinquished to the oppressed minority effected by the wrong doing. The rationale behind this line of thinking is the insight that "we (society) must acknowledge the significant effect of the distance between the speaker's social location and those being spoken for..."23

Putting this way of thinking that is grounded in social justice into practice, a white, ablebodied, middle class, rural conductor might decide to program Joel Thompson's The Seven Last Words of the Unarmed with the intention of beginning a discussion within the community created by the choir members and the individuals in the audience that can be taken past the walls of the performance hall. With conscious awareness that the conductor's social location is significantly removed from the men the piece is written about and the composer, as often as possible in the preparation of the performance one should relinquish the power of telling the existing stories, as well as creating a new narrative, to those located closer to the issues surrounding race. Respectfully engaging with and presenting a social justice topic while constantly finding willingness to reevaluate one's understanding lies at the center of effectively employing social justice as restorative justice in a choral music setting.

\section{Getting in the Work, not in the Way}

American folklore ethnographer Elaine Lawless takes the awareness of not speaking for another into the practice of reflexive ethnography. Her approach directs methodology of the case study to follow in chapter three of this document, informs interpretation of data, and influences presentation of conclusions. Lawless explains she uses reflexive ethnography throughout her process to include, "who we are as we do ethnography, where we are as we write up these

\footnotetext{
${ }^{23}$ Alcoff, "The Problem of Speaking for Others," 7.
} 
ethnographies, and where we are as we offer our interpretations of these materials we study. We are obligated to present ourselves in our texts as we are in our work: humans seeking understanding, engaged in dialogue and interpretation with others." ${ }^{24}$ This approach parallels changes in the field of ethnomusicology as well where the voice of the researcher is not assumed to be more authoritative than the speaker. By acknowledging 'where we are' the biases and preconceptions informing the interpretations of researchers can exist without subconsciously coloring the conclusions. Lawless also employs ideas of Ken Plummer's corrective sociology as she interacts with subjects. These steps occur in research introduced in the following chapters of this thesis and center on the following practices:

1. Paying tribute to human subjectivity and creativity,

2. Paying attention to concrete human experiences (ie, feelings, talk, action),

3. Developing intimate familiarity with experiences through fieldwork

4. Increasing self-awareness of the ultimate moral and political role of the ethnographer. ${ }^{25}$

Respectfully engaging with other humans and presenting a topic accurately with the humility to acknowledge the large space (and thus potential for inaccurate interpretation) between speaker and subject also describes the practice of fieldwork by some modern ethnomusicologists. Applied musicology and medical ethnomusicology, both relatively new branches of the field largely influenced by the innovative work and writing of Gregory Barz, combine to provide a lens for the investigation of choral music as a vehicle for social justice. Barz explains applied musicology, this new approach to fieldwork, as "engaging the scholar in meaningful human contexts" rather than simple data collection. ${ }^{26}$ In a different text he recounts

\footnotetext{
${ }^{24}$ Elaine Lawless, "I Was Afraid Someone like You... an Outsider... Would Misunderstand," The Journal of American Folklore 105, no. 417 (1992): 302, http://www.jstor.org/stable/541758 (accessed November 7, 2017).

${ }^{25}$ Lawless, 304.

${ }^{26}$ Gregory Barz, "Introduction," in Shadows in the Field: New Perspectives for Fieldwork in Ethnomusicology, edited by Gregory Barz and Timothy Cooley (New York: Oxford University Press, 2008), 4.
} 
his work with music groups in Africa during the AIDS epidemic and explains his desire to do more than gather data and present the findings. Barz becomes active in the process of educating, healing, and policy making concerning a social justice issue and as a result admits that he has “given up objectivity and unemotional detachment" from this work. ${ }^{27}$ His three primary goals serve as part of the methodology of investigation of cases studied in the following chapters of this document and illustrate the intersection of applied ethnomusicology and medical ethnomusicology. They are as follows: " 1 . To theorize and attempt to put into practice unusual interdisciplinary and inter-institutional work, 2 . To raise timely questions about the validity and efficacy of musical interventions in disease, 3. To recognize agency and small successes of individual lives touched by the work." ${ }^{28}$ By acknowledging the connections of various disciplines and the unconventional relationship of the art of music as intervention in medical and social issues, Barz provided foundational academic substance and methodology to examine music's intersectionality with disciplines of the scholar's choice.

While the influence of applied ethnomusicology is present in the goals Barz sets forth for himself, so are the foundational elements of medical ethnomusicology. Benjamin Koen defines the key components of medical ethnomusicology's theoretical framework to be the "inclusion of culture and ability to collaborate." ${ }^{29}$ Koen reflects on music's ability to rebuild or 'cure' communities throughout history with statements about music's role as a context and vehicle for “expressing the most deeply embedded beliefs and aspirations of human life and a way to create or re-create a balanced and healthy state of being within individuals, families, and societies." ${ }^{30}$

\footnotetext{
${ }^{27}$ Gregory Barz, Singing For Life (London: Routledge, 2014), 7.

${ }^{28}$ Barz, Singing for Life, 10.

${ }^{29}$ Benjamin Koen, "Introduction," in The Oxford Handbook of Medical Ethnomusicology, edited by Benjamin Koen (New York: Oxford University Press 2008), 10.

${ }^{30}$ Koen, "Introduction" 12.
} 
He also expresses the importance of understanding how culturally contextualized both "music" and "medicine" have become and the lack of uniformity that occurs with either term. The commonality between traditional, biomedical, and holistic approaches to medicine is the underlying goal of creating health and healing. Thus, Koen's understanding of medical ethnomusicology defines "medical" as being "to heal, to cure, to make whole."31

\section{Collaborative Social Justice}

From singing groups of domestic abuse survivors in crisis centers to touring transgender ensembles, choral music making is working to bring attention to social justice issues, provide space for performers to grow and heal themselves, and provide a different narrative to their community. But, the members of these groups are not doing it alone. The entire process is a practice of teamwork and cooperation combined with various types of justice. Collaborative social justice, the term, encompasses two important characteristics of effective social change. First it is the combination of multiple functions of justice; for this research, distributive, commutative, procedural, poetic, and restorative. The various types are not present in equal amounts but are all part of the process. With the underlying goal of correcting inequities (restorative), collaborative social justice creates a space where the common good is valued over the individual (distributive) and decisions are made from a place of inclusivity, not fear or attempts at "political correctness" (poetic). The societal contracts between individuals, groups, and society are honored as best they can be (commutative) and the process, be it conversations on legislation, creating community programs, or music making, is valued over the product (procedural). A singular type of justice cannot solve a multi-faceted issue of social inequity.

\footnotetext{
${ }^{31}$ Koen, "Introduction," 13.
} 
The second elemental characteristic of collaborative social justice is the presence of individuals from each level related to the society inequity, meaning the group of individuals working to address the problem cannot all be members of the minority created by the issue. This is where remembering whose story it is to tell is important. To successfully address a social issue, those experiencing the negative consequences can raise awareness and empathy by sharing their lived experiences with other individuals who are removed from the problem. They should also be included in the restorative justice part of the process to aid in the creation and efficiency of proposed solutions effecting social change. Often the persons with opportunities to share the stories, like authors, television executives, elected officials, are from that group of individuals removed from the problem. In most cases the community members able to offer financial support to host events, sponsor community organizations, or make the donations needed to engage political change are also not members of that minority. Collaborative social justice results from inclusion and participation from individuals in both the minority resultant from existing cultural practices and those privileged to be removed from the experience of inequality.

To investigate this process the acknowledgement of an existing accepted narrative and the rationale behind the creation of that narrative, and the "good" and "bad" sides of it, influenced by critical theory, must occur. The areas where social and/or economic equality and democracy are failing are apparent and the power systems benefiting from those inequities become clear. The "healing" comes as the new counter narrative is created, explored, and brought forth to the community through music. Examining social justice choirs as experiments in applied medical ethnomusicology provides more needed scholarship in both relatively young fields and expands upon the intersection both Gregory Barz and Benjamin Koen describe of 
music, culture, and multi disciplines offering a fresh approach to promote health and healing in individuals and communities. 


\section{Chapter 2}

\section{Justice as an Invitation: "Come Together, Right Now, Over Me."}

The struggle to achieve social justice is at times overwhelming. Art delivers social justice themes to an audience in a way that is aesthetically pleasing, yet no less visceral for its beauty. Whether in the classroom or in a grassroots space, art remains a powerful tool for learning about and expressing actions for change. ${ }^{1}$

\section{$\underline{\text { I. Building Relationships }}$}

In countries across the globe groups of people join together to make music in hopes of changing their communities for the better. Critical pedagogy suggests the study of these groups center on the identities, experiences, and process of engaging communities in critical discourse that links their individual lives to the collective experience and moves toward change. ${ }^{2}$ The term "musicking" gives name to that process.

Christopher Small directly addresses the outdated idea of music being a "thing" that is passed from composer to performer and arrives at a stopping point with an individual in the audience with discussion of his term "musicking." Instead he views music not as a thing but as an activity, requiring its own verb to express the very fact it is something that people do. ${ }^{3}$ His formal definition is as follows: "To music, is to take part in any capacity, in a musical performance, whether by performing, by listening, by rehearsing, or practicing, by providing material for performance, or by dancing." ${ }^{4}$ By indicating no demarcation or hierarchy concerning the actions of performers and the actions of all other individuals involved in the performance, the focus is placed on the activity itself. An activity that everyone present shares the responsibility of

\footnotetext{
${ }^{1}$ Jennifer Miles and Laura Dawson, "The Art of Social Justice," Humboldt Journal of Social Relations 34, (2012): 2, http://www.jstor.org/stable/humjsocrel.34. (accessed January 31, 2018), 3.

${ }^{2}$ Miles and Dawson, 3.

${ }^{3}$ Christopher Small, Musicking: The Meanings of Performing and Listening (Middleton: Wesleyan University Press, 2011), 2.

${ }^{4}$ Small, 9 .
} 
defining the quality and nature of, as well as its success or failure. ${ }^{5}$ Small also explicitly states the importance of maintaining no concern for valuation when observing or researching musicking. The only value lies in the action of what people do, and not in the nature or meaning of musical objects or the music itself. ${ }^{6}$ This approach to choral music runs parallel with the earlier definition created from the writing of Lee Higgins, that justice is an invitation to take a step toward another human being. ${ }^{7}$ Viewing musical performance as an interaction between human beings provides opportunity to ask what is really going on in that society and the lives of everyone involved in the performance rather than simply what one thinks the music means.

By Small's definition, all musicking centers on the opportunity and experience of human interaction. Thus, choral musicking becomes an exercise in human interaction with human instruments. Karen Ahlquist shares a similar thought to Small's: "Indeed, the human relationships at the center of choral life can flesh out the composer-work-reception model common in historical studies."8 The historic approach in Western music-history writing pertaining to choruses and choral music emphasizes composers and the pieces rather than musicking and structure of organizations. That approach does not leave space for exploration of the human relationships at the center, the artistic goal that unified a group of unique individuals to work toward a performance, or the value and process of building trust, identity, and appreciation in the group and the community. There would be no way to explore how "singers give an acoustic form to shared experiences," or learn from the experience of audience members

\footnotetext{
${ }^{5}$ Small, Musicking, 10.

${ }^{6}$ Small,, 8.

${ }^{7}$ Higgins, "Hospitable Music Making: Community Music as a Site for Social Justice," 448.

${ }^{8}$ Karen Ahlquist, Chorus and Community (Urbana: University of Illinois Press, 2006), 8.

${ }^{9}$ Gregory Barz, “'We Are from Different Ethnic Groups but We Live Here as One Family': The Musical Performance of Community in Tanzanian Kwaya," in Chorus and Community (Champaign: University of Illinois Press, 2006), 23.
} 
who, as a result of the specific identity a chorus displays, may be "forced to face unanticipated questions about their own society."10

Ahlquist boasts other reasons for an ethnomusicological/ethnographic/folklorist approach in continuing scholarship into choral musicking as she discusses what exactly a chorus is and why they are continuously a chosen method of musicking for individuals. She believes fieldwork in choral musicking studies to involve examining how the group functions as a musical instrument and a presenter of text in social, economic, religious, educational, and/or political arenas, both as music and as people. ${ }^{11}$ The musical appeal and symbolic value of choruses remain despite their outdated models and sinking cultural standing. The most common, recent choral example for Western music developed from eighteenth-century ideas of individuality and freedom of association, later examined in documentation of nineteenth-century German male choruses. ${ }^{12}$ These groups formed as result of a shared common interest and were considered political and social developments to be studied. One well-known example were the groups and festivals that emerged from a shared interest in the revitalization of J.S. Bach's choral music.

A partial explanation of choral musicking's longevity lies in a simple fact. Forming a chorus is relatively cheap as the primary resource needed is not money but people willing to invest their time and the instruments are readily accessible. Perhaps the missing element of the staying value of a seemingly antiquated practice like choral singing lies in its ability to be adaptive. Chorus is a flexible instrument whose music is used in innumerable ways to support any number of diverse events, groups, or ideas. ${ }^{13}$

\footnotetext{
${ }^{10}$ Metzelaar, "Spiritual Singing Brings in the Money: The Fisk Jubilee Singers Tour Holland in 1877," in Chorus and Community (Urbana: University of Illinois Press, 2006), 167.

${ }^{11}$ Ahlquist, Chorus and Community, 2.

${ }^{12}$ Ahlquist, 3.

${ }^{13}$ Ahlquist, 4.
} 
Most choirs offer a mixed approach of formal and informal music performances. For example, many American church choirs can perform a stately focused concert of traditional Western European influenced choral music for celebrations like Christmas and Easter and then burst into improvisatory based spirituals, bluegrass versions of beloved hymns, or a contemporary Christian work the following week. A mixed approach to the study of choruses is emerging from the work of historians, anthropologists, ethnomusicologists, American music scholars, and scholars of religion, cultural, and women's studies all addressing intersectional elements of music and their specific fields of study. This innovation is the result of necessity for researchers pursuing an understanding of choral musicking. It takes into consideration the various facets of choral musicking and acknowledges "that a chorus is not just one thing, but an adaptable idea of community that places serious attention to matters artistic at the center of its world."14

\section{Community Becomes a Chorus}

Community is described by Gregory Barz as a group of people that gather for a reason and that "reason may be to remember and recall, to share, or to create new experiences." 15 His work as a medical ethnomusicologist studies the practice of community-based memory work and music's position within that ongoing process of cultural engagement and change in Africa, specifically, Uganda. His practice of applied ethnomusicology finds him advocating for better medical care, individual rights, and general empowerment of those who are HIV positive. ${ }^{16}$ Barz investigates the social networks, power relationships, and cultural structures that facilitate the

\footnotetext{
${ }^{14}$ Ahlquist, Chorus and Community, 10.

${ }^{15}$ Barz, "“We Are from Different Ethnic Groups but We Live Here as One Family': The Musical Performance of Community in Tanzanian Kwaya," 19.

${ }^{16}$ Barz, Singing For Life, 2.
} 
arts (music/drama/dance/visual art) as a major source of education, prevention, and healing in the treatment of HIV/AIDS. ${ }^{17}$ This study exemplifies the unexpected nature of research as initially Barz was completing doctoral fieldwork focused on the post-colonial process of "musical indigenization" of Lutheran churches in the area. However, after extensive research in these African communities, he came to understand the power that musical traditions hold and their ability to not only influence social behavior but spread educational information. He also came to understand there was a much more prevalent and pressing matter to be addressed in Uganda. The successful movement of combating HIV/AIDS with local cultural performances that offer support, empathy, and knowledge surfaced during his fieldwork and interviews with performers, traditional healers, political figures, and individuals "living positively."18

At the center of this methodology lies Barz's concept of cultural memory work and specifically the terms "memorying" and "rememorying." Mieke Bal, a scholar whose research in memory recall is used by Barz as foundational knowledge in his own work, explains that memory generally forms as an individual undergoes a process that exposes them to the memories of others, specifically those older than the individual. ${ }^{19}$ The term memorying encompasses the practice of intentionally giving memory to an idea, thought, or message and functions as an inherently performative and purposeful action. ${ }^{20}$ Applying these explanations, school children form memory of Christopher Columbus as the revered man accredited with discovering America from an older individual, a teacher, who expresses their memory and engages the children in the

\footnotetext{
${ }^{17}$ Barz, Singing for Life, 3.

${ }^{18}$ Gregory Barz and Judah Cohen, The Culture of AIDS in Africa: Hope and Healing Through Music and the Arts (New York: Oxford University Press, 2011), 12.

${ }^{19}$ Mieke Bal, Jonathan Crewe, and Leo Spitzer, Acts of Memory: Cultural Recall in the Present (Hanover: University Press of New England, 1999), 51.

${ }^{20}$ Gregory Barz, "The Performance of HIV/AIDS in Uganda: Medical Ethnomusicology and Cultural Memory," In The Oxford Handbook of Medical Ethnomusicology, edited by Benjamin Koen (New York: Oxford University Press, 2008), 166.
} 
action of performing the idea introduced to them through classroom activities and discussion. This becomes a cultural memory, the term applied as a more direct and applicable alternative to collective memory, as citizens of the United States engage in activities such as celebrating Columbus Day, repeating poems about 1492, and positively referencing him in poplar forms of entertainment like the Broadway musical Hamilton. Cultural memory is not "something of which you happen to be a bearer of but something that you actually perform, even if, in many instances, such acts are not consciously and willfully contrived."21

For Barz, rememorying explains the changes and adaptations of memory that are often necessary and result from active memory work through intentional manipulation of existing memory. ${ }^{22}$ Rememorying functions as both a rejection of historical memory and a conduit of new memory forming performances. To continue with the previous example, though it is not musical, the rememorying of Christopher Columbus in the cultural memory of the United States occurs as those school children mature and are introduced to a different memory. Articles, documentaries, and other popular media mediums share information about the nature of his treatment of Native Americans and his lack of information and navigational failure. This rememorying allows individuals to 'adjust their glasses' and participate in new performances, such as cities renaming Columbus Day celebrations as Indigenous People's Day events, that reinforce the rememorying work. The resulting newly defined sense of identity emerges through the process of rememorying.

Memory categories are another important foundational element in Barz's approach to rememorying is also taken from the research of Mieke Bal. The first category is known as urnarrative or inner-core narrative and describes the memories individuals retain that are

\footnotetext{
${ }^{21}$ Barz, "The Performance of HIV/AIDS in Uganda," 166.

${ }^{22}$ Barz, "The Performance of HIV/AIDS in Uganda," 165.
} 
responsible for the formation of everyday habits and inform their conditional behaviors. ${ }^{23}$ Bal's next category are narrative memories which differ from habitual memories in that they require constructing a present, living story from a series of recalled events. The final category which becomes ever present in the methodology and fieldwork of Gregory Barz is that of traumatic recall. This narrative functions as a healing activity where traumatic memories are "legitimized and narratively integrated in order to lose their hold over the subject who suffered the traumatizing event in the past." 24 While the traumatizing event occurred in the past, traumatic memories occur very much in the present, but Barz finds musical performances facilitate the cultural process of memorying and rememorying long-term healing success.

\section{Actively Rememorying HIV/AIDS}

Uganda has a public policy of openness regarding HIV/AIDS which became labeled as the country's “open secret." These government policies were an attempt to move beyond the stigma and medical label of HIV positive and employed a deliberate manipulation of linguistics; rather than HIV positive, the normative phrase became "people living positively." ${ }^{25}$ Barz identifies the work of The AIDS Support Organization (TASO)'s musical drama group as a driving force behind the changed cultural memory and shifted attitude associated with the disease of HIV/AIDS in Uganda. The group initiated a change from musical texts in songs originally about death and sympathy to lyrics of empowerment and hope. TASO's public relations officer Anne Kaddumukasa relayed the process of creating and adopting new texts that were overseen by the health-care administration in hopes of "redressing the negative historical

\footnotetext{
${ }^{23}$ Barz, "The Performance of HIV/AIDS in Uganda," 167.

${ }^{24} \mathrm{Bal}$, Crewe, and Spitzer, Acts of Memory: Cultural Recall in the Present, viii.

${ }^{25}$ Barz, "The Performance of HIV/AIDS in Uganda," 165.
} 
baggage inherent in AIDS in Uganda in many communities. ${ }^{26}$ The noted result was a changed memory of HIV/AIDS among those who heard the songs and the noticeable shift in cultural attitude toward the disease.

Consider here the song "Akawa Kangema" (2007) (I Caught the Virus), written and performed by HIV positive musician Walya Sulaiman and his performance group, People with AIDS Development Association (PADA). It also references the Integrated Development Activities and AIDS Concern group in Iganga (IDAAC).

When I caught the virus at home I had a real problem

Relax and I will narrate the point

I used to spend the date at home mourning the disease

I used to spend the day at home fearing

I used to spend the day at home thinking of suicide

But then I remember the children

There was a day when my sister came ad told me that I should go to IDAAC in Iganga They look after many AIDS victims

But then my aunt stopped me from going to IDAAC

She told me that people who go there have their years cut off

"The drugs they give out from IDAAC bear the sign of a spade on the cover"

"When you take their drugs, you spend a very limited time on earth"

My aunt convinced me to no go to either IDAAC or TASO

But my friends, what rescued me was sensitization and counseling

I used to fear drugs, but then PADA taught me to no longer fear

I used to fear taking food, but then PADA taught me to no longer fear

I used to fear IDAAC, but then PADA taught me to go to IDAAC

I used to fear TASO, but then PADA taught me to go to $\mathrm{TASO}^{27}$

This song is a helpful example of why an understanding of existing cultural structures

and practices are necessary to engage with rememorying. The memories held by the aunt in this text exemplify those of many members in the community. In Ugandan culture medical treatment also involves religious treatment and traditional holistic healers. When Western medicine techniques, terminology, and doctors rushed into Africa to combat the AIDS epidemic there was

\footnotetext{
${ }^{26}$ Barz, "The Performance of HIV/AIDS in Uganda," 165.

${ }^{27}$ Barz, 181.
} 
hesitancy and fear among communities as there was no memory or familiarity of such medical treatment. Sulaiman's decision to use a song illustrates his cultural understanding of many contemporary communities in Uganda which "use music both to preserve these historical understandings and to advocate for the need to change the harmful nature of certain historically rooted myths, beliefs, and conceptualizations about the disease." ${ }^{28}$ Barz interviewed a traditional healer, Maboni Nabanji, who echoed the need for texts that addressed the complexity of conflicting cultural memories and disseminated universal information about the disease. Nabanji says, "If we can all make sure that people are getting the same accurate messages and information in the church as they are getting from me and from doctors, then, well, we are surely all together in this struggle." 29

The accomplishments of these musical performance groups provide concrete examples of choral musicking as an efficient vehicle for social justice. To apply criteria from Chapter One of this thesis, the issue of injustice occurs because the 'worth, dignity, and preciousness of human beings' described by Estelle Jorgensen is not present for all HIV positive individuals in Uganda. ${ }^{30}$ When Barz published Singing for Life: HIV/AIDS and Music in Uganda in 2014 the following statistics were true: Only $10 \%$ of the population in Uganda have access to medical facilities and there is one doctor to every 20,000 people; While infection rates are down from $30 \%$ to $5 \%$ over 10 years there are still 2 million orphans and 1 million persons living with AIDS needing care that cannot be provided; Less than $2 \%$ of those requiring antiretroviral drugs can afford them. ${ }^{31}$ These statistics bolster the humane and necessary option of music as an avenue of

\footnotetext{
${ }^{28}$ Barz, "The Performance of HIV/AIDS in Uganda," 181.

${ }^{29}$ Barz, 165.

${ }^{30}$ Jorgensen, "Intersecting Social Justices and Music Education," 8.

${ }^{31}$ Barz, Singing For Life, 4.
} 
intervention and care. "Music often mitigates the socioeconomic effects of illness by directly supporting caregivers, controlling pain, and providing counseling. ${ }^{32}$

The existing master narrative during the onset and beginning years of the pandemic, influenced by the existing powerful social structures of church and government, painted HIV/AIDS as a condition contracted by 'bad' people. The socially acceptable behavior toward HIV positive individuals is to view them as victims and follow through with blame, avoidance, and pity. Also, many myths and cultural beliefs arose that did not reflect accurate or factual information about the disease. These practices do not exist only in sub-Saharan Africa. The following quote from Barz is just as applicable in the United States with the current epidemic of opioid addiction. "(This) widespread phenomenon is largely the result of deep cultural issues related to the politics of local and regional economies as well as conflicts between local and foreign health-care systems." ${ }^{33}$ Considering music as medicine and musicking as treatment for disease requires rememorying to be seen as possible restorative justice.

Jorgensen's concept of restorative justice, the process of correcting past inequities, requires the willingness to rethink and rework traditional practices so that individuals who have been wronged are truly restored. ${ }^{34}$ Rememorying work through musical performance strives to introduce long-term solutions and encourage social change. To apply Lee Higgin's observation of justice, the musical performances are groups of humans making promises to one another. ${ }^{35}$ Most of the musicians writing and performing these songs are 'living positively' and use music to relate to others infected with HIV/AIDS and educate all members in the community. The promises they make to the humans around them include honest reflection of their experience

\footnotetext{
${ }^{32}$ Barz, Singing for Life, 4.

${ }^{33}$ Barz, 5.

${ }^{34}$ Jorgensen, "Intersecting Social Justices and Music Education," 12.

${ }^{35}$ Higgins, "Hospitable Music Making: Community Music as a Site for Social Justice," 448.
} 
with the disease, accurate information about treatment and counseling services they utilize themselves, and proof that it is safe to be hopeful that one might obtain a good quality of life while living positively.

Many of these musical performance groups are village-based women's ensembles whose performances have become integrated into efforts of local government and health-care organizations in Uganda as a formidable option to combat the disease of AIDS. Aida Namulinda, the leader of one such group named Bwoyidha Oyega Group expresses how pertinent it is that music be involved to share a message with her community. "No one will listen to us unless we bring out drums! No one will listen to us talk about Silimu -AIDS- unless we dance!"36 This is not an issue of ego or performance reception for Namulinda; it is imperative risk management and medicine as there are no other preventative measures available to the people in her village to learn about or fight AIDS. ${ }^{37}$ Musical performance is the most effective and immediate means available to these women to spread information related to medical and health-care issues.

Musicking brings the village women together and influences the women's groups to function as social networks more than choirs or dance ensembles. The women build a network of connection that allows members to raise generations of orphans, care for other members of the group and village in childbirth, death, and all events in between. It provides an outlet to educate their village and arrange for the care they will ultimately need for themselves and their children as the virus takes over their bodies. ${ }^{38}$

Through this activity, the art of social justice is observed to be at work as musical performance art draws from culture while simultaneously producing it. One also observes social

\footnotetext{
${ }^{36}$ Barz, Singing For Life, 81.

${ }^{37}$ Barz, 82.

${ }^{38}$ Barz, 97.
} 
justice functioning as commutative justice. The implied contractual obligation musicians in Uganda feel between themselves, their groups, and society is apparent in the value placed in musical performance. Singing texts to encourage blood testing, loyalty to sexual partners, and safe sex measures allows performers to fulfill an intrinsic duty to pass along methods of prevention to those who need it. Social justice as poetic justice is notable in many stories captured in Barz's fieldwork, specifically with individuals like Aida Namulinda. A member of the minority twice over as both a woman and an individual living with HIV, she finds value to her community through her work with the women's group. When villagers listen to her songs, her story is shared, her existence valued, and the disease becomes less stigmatized. Her musicking aids the retention of her natural right to communal happiness.

\section{Choruses Become Community}

The second group of individuals examined to illustrate musicking in hopes of social justice are found in the United States and address the injustice surrounding the lesbian, gay, bisexual, transgender, queer or questioning, and intersex (LGBTQI) community. Some rememorying work around the subject of homosexuality has already occurred as its categorization as a mental disorder or disease in 1974 was corrected in $1987 .{ }^{39}$ Well-known figures in popular culture speaking out on television and in print media, as well as accurate information concerning prevention and treatment during the AIDS epidemic of the 1980s and early 1990s reformed cultural memory. And in later years the success of Broadway musical RENT (1996) and popular television shows like Will and Grace (1998-2006) and Queer Eye for the Straight Guy (2003-2007) assisted the move toward tolerance and inclusivity. The issue

\footnotetext{
${ }^{39}$ John Gonsiorek and James Weinrich, Homosexuality: Research Implications for Public Policy (New York: Sage Publishing, 1991), 17.
} 
remaining in many towns and communities is not the disease of AIDS but a dis-ease, or discomfort, with individuals who identify as part of the LGBTQIA community and the resultant injustice they experience.

Though contrasts between the groups are plentiful, a unifying theme emerges in the research of Gregory Barz in Uganda and Julia Balén in America. They both find the most successful method to produce social change through choral musicking is rememorying, or as Balén terms it, counterstorying. Counterstories are successful because they not only challenge unjust social norms and master narratives but offer a relatable and accurate alternative. Similar to Barz in his desire to understand the cultural memory of HIV/AIDS in Uganda, Balen emphasizes the importance of understanding the function of the master narrative. These stories provide all the material from which cultural identities are constructed, define expectations of individuals, and set limitations for the roles different people are permitted to assume in any social settings. ${ }^{40}$ The strength of these stories is renewed daily through repetitive variations that affirm the 'rightness' of social norms and can be found in matters ranging from law to popular music, advertising to medicine. This shared social narrative touches every part of conscious and sub conscious activity; it also denies recognition and value to many members of society who are restricted by its version of good, right, and just.

Every group of people who are denied full social recognition and value must begin the journey of social change by developing safe places where they can counter the social narratives that deny them dignity and affirm their stories... and thereby experience being held in their full human dignity. ${ }^{41}$

As the larger culture in the United States denied dignity to many citizens in the LGBTQI community, those individuals created a space where other humans accepted them as they viewed

\footnotetext{
${ }^{40}$ Julia Balén, A Queerly Joyful Noise: Choral Musicking for Social Justice (New Brunswick: Rutgers University Press, 2017), 6.

${ }^{41}$ Balén, 15.
} 
themselves. In response to the backlash of gay liberation in the 1970s and second wave feminist movement, gay choruses formed first in large cities in the United States. ${ }^{42}$ These choruses provided community at a time of severe loss and grieving and a space for emotional support and healing. ${ }^{43}$ Balén suggests the reason for such continued success with choruses is their nature of both communal joy making and value for social justice work. Gay men's choruses were later followed by lesbian choirs, LGBT choirs, and all variations and combinations of the LGBTQI community members as queer musicking became a social practice with purpose. ${ }^{44}$

\section{$\underline{\text { Creating a Counter Narrative }}$}

Most available scholarship focuses on gay men's choruses as they were the first category of LGBTQ choral groups and have been in existence the longest, specifically the movement's founders, the San Francisco Gay Men's Chorus. This group's history exemplifies the practice of choral musicking, as their act of singing together organized and claimed social power in a time of need. Formed only one month before the assassination of openly gay California politician Harvey Milk and Mayor George Mascone in 1978, the San Francisco Gay Men's Chorus got its start in a most unexpected manner. The group met on the steps of City Hall following a spontaneous candlelight procession and performed an English version of a hymn composed by Felix Mendelssohn, Thou Lord, Our Refuge. ${ }^{45}$ This musical performance directly addressed the

\footnotetext{
${ }^{42}$ Frances Bird, "Singing Out: The Function and Benefits of an LGBTQI Community Choir in New Zealand in the 2010s," The International Journal of Community Music 10, no. 2 (July 2017), 10.1386/ijcm.10.2.193_1 (accessed October 26,2017), 193.

${ }^{43}$ Shannon Henderson and Stan Hodges, "Music, Song, and the Creation of Community and Community Spirit by a Gay Subculture," Sociological Spectrum 27 (January 2007), (accessed November 11, 2017), 52.

${ }^{44}$ Balén, A Queerly Joyful Noise, 10.

${ }^{45}$ Casey Hayes, "Community Music and the GLBT Chorus," The International Journal of Community Music 1, no. 1 (March 2008) 10.1386/ijcm.1.1.63/0 (accessed July 2, 2018), 66.
} 
master narrative that the lives of gay men are not valuable. Their communal act of singing in this public space as openly gay men made a political statement in homage to Milk but also actively affirmed their right, and the right of those protesting with them, not only to life, but also to beauty, grief, and joy. ${ }^{46}$

Their decision to perform a religious text offers another opportunity to provide a counterstory. As many LGBTQI people were considered degenerate, most received a message either literally or implied that they were not welcome in churches or other spaces used for religious purposes. As Balén gathered data for A Queerly Joyful Noise: Choral Musicking for Social Justice she uncovered a similar sentiment in numerous interviews: the parallels between the role of churches and the role of these choruses in many members' lives. ${ }^{47}$ The second powerful counter narrative offered on the steps of City Hall that day was the result of repertoire choice; not the composer, not the specific piece, but the genre - a hymn. Gay men actively affirmed their vision of themselves as individuals worthy of being welcome in all spaces by practicing religious ideals of love and acceptance.

In more recent years the San Francisco Gay Men's Chorus continues to meet its commitment to increase tolerance and awareness by performing in politically, socially, and religiously conservative regions of the United States. ${ }^{48}$ Members spoke about the importance of finding efficient counterstories that interrupt the narrative that LGBTQI individuals are 'less than' but also offer healing for those identities already damaged by the existing story or whom have not identified at all. In one interview, a member recounted the following story:

\footnotetext{
${ }^{46}$ Balén, A Queerly Joyful Noise, 42.

${ }^{47}$ Balén, 38.

${ }^{48}$ Russell Hilliard, "A Social and Historical Perspective of the San Francisco Gay Men's Chorus," Journal of Homosexuality 54, no. 4 (June 2008) https://doi.org/10.1080/00918360801991208 (accessed January 30, 2018), 357.
} 
A straight man, a father came to a chorus concert and had a wonderful experience and so forth. And just a year or two later, his son actually came out to him, and he took his son to a chorus concert later after that because he wanted his son to experience a positive gay environment. I think that's what we can hope we do...As a group, we're working on collecting something together that celebrates our lives, not just our sexuality, but, you know, ourselves as human beings, as artistic being, and the uniqueness that we have and present to the public. ${ }^{49}$

Another established chorus going about the work of social justice through their musicking is the Twin Cities Gay Men's Chorus. Many choruses and choirs commission pieces, some are new arrangements, some new works, but queer choruses have also worked to slowly incorporate mainstream choral musicking with queer experiences. The Twin Cities Gay Men's Chorus provides a successful example in their reworked version of Tomie dePaola's 1979 children's book Oliver Button Is a Sissy, retitled Oliver Button Is a Star. ${ }^{50}$ By revisioning the story of a boy who prefers to dance and sing to playing sports into a mixed-media movie, the video and by proxy the chorus has been shown in countless elementary schools as part of antibullying campaigns and opened up a dialogue with children about how they view boy roles and girl roles. In other words, they provide a counterstory that questions existing social definitions and expectations while using choral music to invite viewers to live in space defined by queer experience.

Whether singing love songs or even religious music as written (while obviously staging these within a queer context), changing pronouns to make queer identities and relationships explicit, revising lyrics to well-known songs to create space to normalize and celebrate queer identities, or commissioning everything from anthems to musicals to oratorios, queer choral musickers use this highly emotive form to make more tangible for their audiences the loves and pains and joys and sufferings of queers, thereby humanizing identities that are still systematically denied full humanity. ${ }^{51}$

\footnotetext{
${ }^{49}$ Balén, A Queerly Joyful Noise, 42.

${ }^{50}$ Balén, 35.

${ }^{51}$ Balén, 35.
} 
The result demonstrates Miles's explanation of the functionality of art in social justice, as it asks the listener or viewer to exist in a space, for a moment, where they may not fully comprehend their surroundings.

Though the choral groups investigated in this chapter offer stark contrast to one another, fundamental commonalities exist. Both the singers living positively in Uganda and the members of the American LGBTQI choruses ask their audience members to exist in a space that may be temporarily uncomfortable due to lack of lived experience. The groups are aware of the current cultural memory as they live in the society where they experience the resultant inequities on a daily basis. Thus, they have succeeded in the first step of identifying the current master narrative. They both actively work to craft a counter narrative that is accurate and develop methods to share that story with their communities in approachable and often entertaining ways. An increased sense of worth and ability to experience joy are outcomes similarly expressed by members from these vastly difference groups and an improved grasp of self-identity as well as group identity assists members as they present their counter narrative and relate to the society around them. 


\section{Chapter 3 \\ Justice as a Practice: Social Change through Musicking}

The previous chapter discussed the social justice work of two very different groups of people. Their primary commonalities are the practice of identifying an existing cultural narrative that promotes social injustice by reinforcing social inequity and their ability to create a new counternarrative that provides the created minority an opportunity to share their lived experience in hopes of spurring social change. Both groups, those in Uganda working to combat the HIV/AIDS pandemic and those in the United States striving for education and acceptance of LGBTQI individuals, shared these new narratives over a significant amount of time, years and even decades for some. The case study examined in this chapter offers a glimpse of how to illustrate and share a counter narrative but does so over an extremely short period of time in comparison, a few months of preparation and a three-day summit known as Concept Freedom.

\section{Columbus, Ohio: The Perfect Storm}

Weigel Hall at The Ohio State University is much like any other School of Music building on a large urban American university campus. The university itself was founded in 1873 and music instruction followed shortly thereafter. The School of Music was formally established in 1945 and the space housing it was named for the first director, Eugene J. Weigel. ${ }^{1}$ Multiple floors house performance spaces, classrooms, practice rooms, and offices. There is a general sense of busyness and creativity in the space. In its basement is a large cement floored rehearsal area with various ethnic percussion instruments encased in cages and hundreds of music stands

\footnotetext{
${ }^{1}$ Bruce Carr, "Ohio State University School of Music" Oxford Music Online, accessed July 4, 2018, http://www.oxfordmusiconline.com/view/10.1093/gmo/9781561592630.001.0001/omo-9781561592630e-0000050073.
} 
stored on the sides. In the middle sits a single grand piano, in front of which is a large conductor's podium and a mirror that runs the length of the room on the far wall from the entrance. This is where I met the current members of The Ohio State University's Women's Glee Club and their strikingly focused artistic director, Dr. Kristina Caswell MacMullen.

The Ohio State University is located in Columbus, Ohio, the state's capital and largest city by population with a reported number from 2010 of 787,033 citizens in Columbus and $1,836,536$ citizens in the Columbus Metro Area. ${ }^{2}$ In 1812 planning began to make Columbus the political center of the state due in part to its ideal location in a flat central area at the junction of the Scioto and Olentangy Rivers. Significant geographical factors that lead to economic and population growth were the opening of a feeder branch of the Ohio and Erie Canal in 1831, first railroad in 1850, and completion of the section of the Cumberland National Road connecting Ohio to Maryland in $1836 .{ }^{3}$ Industrial businesses were attracted to the area due to the convenience of railroads and steam power from nearby water sources; as a result, Columbus experienced unprecedented industrial growth after $1940 .{ }^{4}$ Moving into the twenty-first century, the city continues to boast a healthy local economy emphasizing health and medicine, high technology, and manufacturing fields. The current favorable characteristics of its geographic location include mainline railroads, an international airport, and an extensive highway network. ${ }^{5}$

The extensive highway systems converging near its center and high population make Columbus an attractive city for many, but also qualifies it to be a prime location for human

\footnotetext{
${ }^{2}$ Stephen Klein, "Columbus, Ohio, United States," Encyclopedia Britannica, accessed July 4, 2018, https://www.britannica.com/place/Columbus-Ohio.

${ }^{3}$ Mansel Blackford, Columbus, Ohio: Two Centuries of Business and Environmental Change (Columbus:

The Ohio State University Press, 2016), 5.

${ }^{4}$ Klein, "Columbus, Ohio, United States."

${ }^{5}$ Blackford, Columbus, Ohio, 207.
} 
trafficking. With immediate access to United States Interstate 71 running north to south from the Canadian border to the gulf coast in Louisiana and United States Interstate 71 providing a route across the country from east to west, Columbus experiences a high rate of commercial trucking traffic and provides easy access to any region of the country. ${ }^{6}$

Following a dramatic increase in the number of sex trafficking and human trafficking cases in Ohio in the early 2000s, officers began collecting data, publishing research, and creating lists of conditions helpful to identify locations, traffickers, and victims. Two primary cities known currently for activity of human trafficking are Toledo and Columbus. In a 2008 article law enforcement officers highlight Columbus's preeminence as a prime location for trafficking due to the following factors: proximity to international boarder, extensive highway systems, growing immigrant population, proximity to large universities, international corporations, agricultural industries, and military bases. Other contributing influences identified included the growing poverty rate and teen birth rates, which are both greater than the state average, and its status as the state capital makes it a heavily visited location. ${ }^{7}$

Human trafficking is a growing global concern but is ultimately a problem identified locally. ${ }^{8}$ Existing research shows individuals involved with sex trafficking are often identified to be local and those involved with human trafficking are mainly foreign nationals; this research may not be conclusive as many precincts do not have existing protocol for trafficking nor do they reach consensus on the definition of "trafficking" or "victims." The Trafficking Victim's

\footnotetext{
${ }^{6}$ Jeremy Wilson and Erin Dalton, "Human Trafficking in the Heartland: Variation in Law Enforcement Awareness and Response," Journal of Contemporary Criminal Justice 24, no. 3 (August 2008) http://journals.sagepub.com/doi/10.1177/1043986208318227 (accessed July 3, 2018), 296.

${ }^{7}$ Wilson and Dalton, 298.

${ }^{8}$ Wilson and Dalton, 297.
} 
Protection Act of 2000, reauthorized in both 2003 and 2005, provides the following definition accepted by Wilson and Dalton in their article and in this research document:

(A) sex trafficking, in which a commercial sex act is induced by force, fraud, or coercion or in which the person induced to perform such act has not attained 18 years of age; or (B) the recruitment, harboring, transportation, provision, or obtaining of a person for labor or services, through the use of force, fraud or coercion for the purpose of subjection to involuntary servitude, peonage, debt bondage, or slavery. ${ }^{9}$

Their research also found that contrary to the existing master narrative, more trafficking victims are lured or recruited than abducted, and the role women play in recruiting and enforcing the trafficker's rules is more substantial than previously identified. This information influenced the creation of effective protocols in Toledo resulting in more juvenile cases being correctly classified as trafficking, with juveniles involved labeled victims rather than offenders, and this protocol informed part of the training process for law enforcement officials. ${ }^{10}$ In Columbus, however, juveniles participating in sex rings run by adults were arrested for prostitution and processed through a juvenile justice system that does not examine possible trafficking issues. Some officers also stated the overwhelming number of runaways, who are often recruited or abducted, is a constant and often overshadowed by the robberies, murders, and other crimes considered to be "more violent."11 These young women and men who are categorized as runaways are often lost to the trafficking industry.

\section{Identifying Injustice: Trafficking Becomes Human}

Combining research with first hand interviews from the members of The Ohio State Women's Glee Club, as well as their accompanist and director, the master narrative or cultural

\footnotetext{
${ }^{9}$ Wilson and Dalton, "Human Trafficking in the Heartland ," 297.

${ }^{10}$ Wilson and Dalton, 302.

${ }^{11}$ Wilson and Dalton, 305.
} 
memory of human trafficking in Columbus emerged. The Ohio State University's Women's Glee Club, established in 1903, is an auditioned ensemble of individuals who identify as female, ranging from freshmen to graduate students. These women come together in the early afternoon each Monday, Wednesday, and Friday of the semester to rehearse and are encouraged to engage in social events with one another and in the community. The group's director, Dr. Kristina MacMullen, described herself as a conductor, teacher, artist. She serves as an assistant professor of conducting and assistant Director of Choral Activities at the University. Her research centers on implementation a mode of expression created by Slovenian conductor Karmina Šilec called Choregie, which combines extra-musical meaning, movement, and design into the performance. As an extension of this practice, she notes that her "programming often includes contemporary narratives, theories, and social justice causes." 12

The Women's Glee Club page on The Ohio State University website, prepared by MacMullen provides the following mission statement:

The organization strives to connect and empower women through music-making and sisterhood by challenging them to find their own voices... One of the organization's main goals is to grow in sisterhood and compassion through bonding and activism...Additionally, The Women's Glee Club aims to bring awareness to marginalized groups through engagement and music. ${ }^{13}$

During my interviews with members of the Women's Glee, I asked about their background with the topic of sex trafficking and/or human trafficking before participating in preparation for and performance at the Concept Freedom summit. Every woman interviewed said that they knew the topic existed, but were not familiar with information, statistics, or the lived experience of those

\footnotetext{
${ }^{12}$ Kristina MacMullen. Kristina Caswell MacMullen. https://www.kristinamacmullen.com (accessed July 4, 2018).

${ }^{13}$ Kristina MacMullen. School of Music: The Ohio State University Women's Glee Club. https://music.osu.edu/wgc/about (accessed July 4, 2018).
} 
involved in the trafficking industry. All but one added that they did not think it was something that happened where they lived. They associated trafficking practices with "third world countries where parents are forced to sell their children because they cannot afford them," or just taking place "somewhere far away from here... removed." ${ }^{\text {"14 }}$ One member remarked that she was assigned to read a book in high school about human trafficking but it was set in the Middle East and felt that despite that assignment and discussion, she was not prepared for the intensity of the Concept Freedom summit.

MacMullen recounts that her passion for human trafficking came from a chance encounter during her first visit to Ohio State University's campus. After being offered the job offsite she traveled to Columbus to see the campus and School of Music for herself. While touring Weigel Hall she passed a bulletin board with a flyer that read "The Price of Life" and had the term 'human trafficking' on it. At the time, in 2010, the term was not well-known, but something about the poster sparked her interest. She turned to online sources to inform herself more about the subject and accepted the position. At his point in her professional career MacMullen's research focus was shifting from her doctoral project focus of J.S. Bach to the work of Karmina Šilec, a modern conductor from Slovenia who creates multi-sensory interdisciplinary performances that always have a theme, message, or a programmatic element. ${ }^{15}$ MacMullen explains:

Her (Šilec) work is always very meaningful in that it addresses truths that are not talked about. And things that are important and of substance that are not peripheral or... I don't know what the right word is... There is a pastor that I knew and he would always say we live in a $90 \%$ world. $90 \%$ of what we do and talk about doesn't matter. And then there's

\footnotetext{
${ }^{14}$ Anonymous, Interview with Women's Glee Club Member by author, Columbus, June 15, 2018.

${ }^{15}$ Kristina MacMullen, Interview with Women's Glee Club director by author, Columbus, June 16, 2018.
} 
this $10 \%$ that we rarely talk about. So Karmina goes there. She gets after the $10 \%$ stuff. And I always admired that and have been inspired by that. ${ }^{16}$

Despite the challenges of relocating to a new area, learning the new university culture, and engagement with an emotionally demanding topic, MacMullen proceeded with her research into the human trafficking industry after accepting the position at The Ohio State University. She speaks of her 'ignorance' of both the topic and what, if anything, Ohio State did concerning the subject. Her internal conversation between the awareness that she was a choir director but desire to do something about human trafficking ultimately led to Concept Freedom, a three-day summit she organized on campus.

So the, Concept Freedom was a marriage of, "Ok I want to make a difference in this world, with I'm just a choir director." There's got to be more than beautiful tone; there's got to be more than performance practice. That is empty, completely empty. It's a vapid pursuit. And as my four-year-old son says, "We have big feelings." I had big feelings about human trafficking and wanted to do something about it. I didn't quite know what I... or how I could do it. I had no idea. But I thought, ok I'm just going to find out what's happening here and see what comes of it. ${ }^{17}$

\section{Concept Freedom: The Process}

MacMullen's research put her in touch with Dr. Kim Jordan, a professor in the university's College of Law. Jordan's experience with the court system in Columbus, particularly of the juvenile courts and human trafficking issues was a primary source for MacMullen as she ventured into local resources for trafficking victims in the local area. Jordan shared the knowledge of Columbus's CATCH Court and connected MacMullen with its presiding judge. $\mathrm{CATCH}$, an acronym for Changing Actions to Change Habits, Court developed in 2009 as a result of Judge Paul Herbert's observation that for many of the women in his court room, it was

\footnotetext{
${ }^{16}$ MacMullen, Interview with Women's Glee Club director by author, Columbus, June 16, 2018

${ }^{17}$ MacMullen, Interview with Women's Glee Club director by author, Columbus, June 16, 2018.
} 
difficult to determine if they were in his presence as domestic violence victims or as a defendant charged with prostitution. ${ }^{18}$ Judge Herbert's research into human trafficking, prostitution, and sexual exploitation confirmed his suspicions that human trafficking was thriving in Columbus. He also found the means of escaping the cycle were currently extremely limited and occurrences of relapse to be high. "He created CATCH Court to provide a path of rehabilitation, recovery, and support." 19 Judge Herbert and law enforcement officers who frequently appear in his court later provided information and organized one of the interest sessions at the Concept Freedom summit.

Jordan also suggested MacMullen read the text Girls Like Us: Fighting for a World Where Girls are Not for Sale, an Activist Finds her Calling and Heals Herself written by Rachel Lloyd, a 'survivor leader.' This text became the foundation for Concept Freedom and the manner with which MacMullen would select and order repertoire for the Women's Glee Club to perform. After reading, MacMullen reached out to the author and invited her to attend the summit. She explained her vision for the event including the cornerstone event, a choral concert telling Lloyd's story as a survivor followed by a question and answer session with the author. Following Lloyd's acceptance of the invitation, MacMullen began the music selection process by focusing on the chapters of the book. Each chapter, titled with a singular verb, lays out the chronology of the average trafficking victims. In order they are: Learning, Risk, Family, Recruitment, Pimps, Johns, Victims, Cops, Staying, Leaving, Relapse, Unlearning, Stigma, Healing, Leadership, and Beginnings. $^{20}$

\footnotetext{
${ }^{18}$ MacMullen, Interview with Women's Glee Club director by author, Columbus, June 16, 2018.

${ }^{19}$ CATCH Court. https://www.catchcourt.org (accessed July 5, 2018).

${ }^{20}$ Rachel Lloyd, Girls like Us: Fighting for a world where girls are not for sale, an activist finds her calling and heals herself (New York: Harper Collins Publishers, 2011), Table of Contents.
} 
During our interview, Dr. MacMullen shared that she was very aware of the importance to stay true to the story as presented by Rachel because it was Lloyd's lived experience and not that of herself or the musicians. As part of the repertoire selection process, MacMullen chose to select a single statement from each chapter that stood out to her as she read and encapsulated the connection of the piece to the chapter. These quotes from Lloyd's book would ultimately be projected on the wall as the performance of the related piece took place. The following excerpt from the concert program reflects the chapter number, title, extracted phrase, selected piece and composer, and function of collective voice.

\begin{tabular}{|c|c|c|c|c|}
\hline$\frac{\text { Chapter }}{\underline{\text { Word }}}$ & $\underline{\text { Title }}$ & Composer & $\frac{\text { Collective }}{\text { Voice as }}$ & Quote \\
\hline Prologue & Tota Pulchra Es & Maurice Duruflé & Teacher & $\begin{array}{l}\text {...but mostly she's } \\
\text { eager to be loved. }\end{array}$ \\
\hline Learning & We Have Come & Abbie Betinis & Exhorter & $\begin{array}{l}\text {...support does make a } \\
\text { difference. }\end{array}$ \\
\hline Risk & Chandelier (solo) & Sia & Victim & $\begin{array}{l}\text {... a flashing neon sign } \\
\text { for danger, abuse, a } \\
\text { tragic ending. }\end{array}$ \\
\hline Family & $\begin{array}{l}\text { The Island of Souls } \\
\text { (solo) }\end{array}$ & Sting & Teacher & $\begin{array}{l}\text {...no need for much } \\
\text { training... it's already } \\
\text { been done. }\end{array}$ \\
\hline Recruitment & $\ddot{U}$ berlebensgrö $\beta$ & Stephen Hatfield & Teacher & ...the trap is set. \\
\hline Pimps & My Man (solo) & Maurice Yvain & Victim & $\begin{array}{l}\text {...stopping the } \\
\text { glorification would be } \\
\text { enough for now. }\end{array}$ \\
\hline Johns & Baracole Chorys & $\begin{array}{l}\text { Jacques } \\
\text { Offenbach }\end{array}$ & Victim & ...most just don't care. \\
\hline
\end{tabular}




\begin{tabular}{|c|c|c|c|c|}
\hline Victims & No Grief & Abbie Betinis & Victim & $\begin{array}{l}\text {...the experience of } \\
\text { victimization is often } \\
\text { disparaged at best. }\end{array}$ \\
\hline Cops & Billy the Kid (solo) & Libby Larson & Teacher & $\begin{array}{l}\text {...there are } \\
\text { undoubtedly good } \\
\text { cops, and still some } \\
\text { with an outright disdain } \\
\text { for the girls. }\end{array}$ \\
\hline Staying & Closer to the Fire & Abbie Betinis & Teacher & $\begin{array}{l}\text {...isolated. exploited. } \\
\text { her entire world } \\
\text { becomes pimps, johns, } \\
\text { and other victims. }\end{array}$ \\
\hline Leaving & $\begin{array}{l}\text { I Cannot Dance } O \\
\text { Lord }\end{array}$ & Stephen Paulus & Teacher & $\begin{array}{l}\text {...if she believes she } \\
\text { has options, resources, } \\
\text { somewhere to go. }\end{array}$ \\
\hline Relapse & $\begin{array}{l}\text { I Loves You Porgy } \\
\text { (duet) }\end{array}$ & $\begin{array}{l}\text { George } \\
\text { Gershwin }\end{array}$ & Teacher & $\begin{array}{l}\text {...it allows us to pick } \\
\text { up one cigarette or } \\
\text { drink after years of } \\
\text { hard-earned freedom. }\end{array}$ \\
\hline Unlearning & $\begin{array}{l}\text { Watching the Moon } \\
\text { at Midnight }\end{array}$ & Stephen Paulus & Teacher & $\begin{array}{l}\text {...like unraveling a } \\
\text { twisted ball of yearn; } \\
\text { each distorted belief } \\
\text { leads to another. }\end{array}$ \\
\hline Stigma & $\begin{array}{l}\text { Inflammatus es } \\
\text { accensus }\end{array}$ & $\begin{array}{l}\text { Giovanni } \\
\text { Pergolesi }\end{array}$ & Victim & $\begin{array}{l}\text {...nothing I did, no one } \\
\text { I met, would erase... }\end{array}$ \\
\hline Healing & Hope Carol & David Conte & Exhorter & $\begin{array}{l}\text {...it is not enough to } \\
\text { provide food, shelter, } \\
\text { and clothing. }\end{array}$ \\
\hline Leadership & $\begin{array}{l}\text { Our Time Has } \\
\text { Come }\end{array}$ & Moira Smiley & Exhorter & $\begin{array}{l}\text {... as girls begin to find } \\
\text { their own voice. }\end{array}$ \\
\hline
\end{tabular}




\begin{tabular}{|l|l|l|l|l|}
\hline Beginnings & $\begin{array}{l}\text { Bright Morning } \\
\text { Stars }(T T B B)\end{array}$ & $\begin{array}{l}\text { Arr. Shawn } \\
\text { Kirchner }\end{array}$ & Exhorter & $\begin{array}{l}\text {...that's how I think } \\
\text { about the girls... } \\
\text { precious stones. }^{21}\end{array}$ \\
\hline
\end{tabular}

My interviews with performers and Dr. MacMullen took place three years after the event's occurrence, January 29-31, 2015, making the majority of the interviewees first-year students at the time and now seniors about to graduate. As a conductor and long-time choir member, I can recount specific performances and pieces of choral music, titles and composers, that resonate with me years and even decades later. I expected the interviewees to have some stand out pieces that encapsulated the event to them filed away because of the beauty of the pieces or the specificity of the lyrics. Instead after asking if there were any pieces of music they felt were a particularly good fit for the event or that they connected with, I largely received responses such as:

I don't really remember the name or words or anything, and they all made sense... but I remember us all sitting and looking up at the soloist and it was really a powerful moment. ${ }^{22}$

I'm trying to think of the name... but we were sitting on our knees and singing this French song. It involved a fabric that your wrapped around yourself that was almost like handcuffs. And that was also a very powerful moment because... it definitely served as a symbol of what people are feeling if they're in that kind of situation. ${ }^{23}$

I loved both of the Betinis? Is that right?... pieces. I don't remember the names but the second one I felt really fit the theme and I personally have experienced sexual assault and sexual violence so that one I felt like was really moving to me.

\footnotetext{
${ }^{21}$ MacMullen, Kristina Caswell MacMullen. https://www.kristinamacmullen.com (accessed July 4, 2018).

${ }^{22}$ Anonymous, Interview with Women's Glee Club Member by author, Columbus, June 15, 2018.

${ }^{23}$ Anonymous. June 15, 2018.
} 
There was a moment in rehearsal when it was just Chamber and we sang that together, in a circle, and really looking at one another. I think that was a moment when I let myself be sad for what happened. And that's when I was like, I'm all in. ${ }^{24}$

For the performers involved, it was not the composer or the pieces that brought meaning to the performance; they found value in the entire process. The preparation process for the event took place from August 2014 through its performance in January 2015. Due to the size of the body of work and other commitments the ensemble would need to uphold, Dr. MacMullen started working on music at the beginning of fall semester. It was at that time she also suggested reading Girls Like Us to her choral musicians. One member's interview recounts her experience as she chose to purchase and read the text at that time. She recalls the women who purchased the text and read it would occasionally go out after rehearsal for coffee or a late lunch. At times they would discuss what they were reading but more often then not they chatted about school and family, and what it was like being a freshman at a large university. They were creating a community for themselves. She also remembered that many of those young women chose to participate by attending local events with survivors that Dr. MacMullen suggested to the group as they prepared for Concept Freedom.

Still focused on gaining understanding and hearing the first-hand stories of survivors, MacMullen attended multiple events with the members of her group and the local survivor community. The Salvation Army in Columbus, a group that would become a primary partner in MacMullen's endeavor, saw the need arising from human trafficking and created a branch of their organization intended to support and serve victims of human trafficking. MacMullen explains that The Well, event hosted by the Salvation Army, occurs each Tuesday. Women who are trafficking survivors and those who are still being trafficked can come in the morning for

\footnotetext{
${ }^{24}$ Anonymous. Columbus, June 15, 2018.
} 
group therapy and art therapy. They are provided a meal at lunch time and welcomed to stay in the space and work on various projects that are sold online as a way of generating funding for the program. At the time of Concept Freedom preparations, the women were creating necklaces. MacMullen and members of Women's Glee came to The Well to spend time with the survivors and make necklaces together. Those necklaces were purchased and put on during the concert in Our Time Has Come, a piece by Moira Smiley which acknowledges the leadership phase of survivors.

\section{Creating Community by Crafting the Counter Narrative}

Continuing to use Christopher Small's definition of musicking, to take part in any capacity, in a musical performance, whether by performing, by listening, by rehearsing, or practicing, by providing material for performance, or by dancing, ${ }^{25}$ to examine Concept Freedom, the extent of involvement from the performers and those providing material for the performance is of note. A significant figure from the local community that came up in every interview was Jennifer Kempton and her foundation, Survivors Ink. Kempton, a tattoo artist and survivor of human trafficking, formed the organization to provides de-branding for survivors who were marked by their pimps. MacMullen invited Kempton to class to share about her foundation and her story as the Women's Glee Club prepared for the performance. She returned in the months following the performance to share with them the effect of the summit on her and her foundation. One member who befriended Kempton on Facebook was a fellow sexual abuse survivor. She reflects on the connection she felt with other survivors and the empowerment of

\footnotetext{
${ }^{25}$ Small, Musicking, 9.
} 
being able to tell their stories through music and in everyday life. Of the twenty-two women

interviewed, four voluntarily disclosed their status as a survivor of sexual abuse.

I got to meet Jennifer Kempton and I got to know her a little bit. And we were Facebook friends and I remember when she was going in to give her deposition on what happened for her trafficker's court case. She made a post about being really afraid about it and I messaged her and shared my experience of when I gave my deposition for the person, you know.

And I said what I experienced is nowhere near what you experienced but when I gave my deposition it definitely gave me closure. And it was scary to see him again, but it gave me closure and it showed me that I do have support around me. And that he was going to go to jail for what he did. And she responded something like, she like thanked me for what I said, but she also said "Don't belittle your experience because it's not as bad as what I experienced. You know, we're all sisters and we're all survivors." It was validating in a way because a lot of the time, you know...

(Interviewer: You don't talk about it?)

Yes. You don't tell your story. I think her saying, no matter how small or big your experience was, it still matters and don't compare it to other people's. It still affected you. Yeah that was definitely a healing moment... Concept Freedom was healing in general. And to see a community come together and show support for people because often times in our society it is glossed over or romanticize, that definitely brought healing as well. ${ }^{26}$

I hoped to interview Jennifer Kempton as part of this research. Her voice as a survivor and her

key role in humanizing the experience to many of the women in the group was more than worthy of documentation in this research. Unfortunately, I learned during the beginning of my interview process with Women's Glee members, that Jennifer had passed away suddenly. The group's collaborative pianist, Casey Cook, shared that after learning of her passing, members of Women's Glee and Dr. MacMullen prepared a piece to sing at her funeral and remarked about how special it was to share that experience with other musicians who knew Jennifer's story intimately. Her foundation continues her work with de-branding and assisting the rehabilitation of survivors of human trafficking.

\footnotetext{
${ }^{26}$ Anonymous, Columbus, June 15, 2018.
} 
Throughout the interview sessions comments concerning the hesitation and frustration of some of the other choir members arose. It was later echoed in my interview with Dr. MacMullen, along with the information that there were approximately 12-15 students that did not register for the ensemble the following fall. As the primary purpose of this case study is to understand successful techniques for addressing social justice through choral musicking, I wanted to know if the subject matter was the reason for the described reaction. Discussing, singing about, and internalizing injustice is an exhaustive process and also runs the risk of being deemed 'too political.' I wanted to hear the story of the performing musicians before I met with Dr. MacMullen and obtained all the facts. In every interview I asked if the individual could explain any negative experiences resulting from their participation in the Concept Freedom summit. And in every interview the primary negative experience was the amount of time needed for rehearsal and preparation. I learned that was the main complaint of the other members whose frustration came up in our interviews. Because of the scope of the event and the timing, the end of the first month back from a nearly month-long holiday break between semesters, the Women's Glee members were overwhelmed and unaware of the time commitment.

This is an area Dr. MacMullen views as a major opportunity for improvement for any similar future events. She is remorseful that she did not effectively communicate the time requirements to the group up front and identifies that part of the reason why she did not was because she did not know herself. ${ }^{27}$ This was a process of evolution and as ideas came rehearsal was adjusted accordingly. In multiple member interviews they also remarked that perhaps that frustration with the amount of additional time spent in rehearsal was also because they could not

\footnotetext{
${ }^{27}$ MacMullen, Interview with Women's Glee Club director by author. June 16, 2018.
} 
see the larger artistic vision at hand. And every woman interview made a statement similar to the following:

There were more positives than negatives and obviously those negatives are just like time commitment things because I mean. We are all extremely busy but the benefits completely outweighed the negative.

Well it was absolutely fulfilling to the human part of me. There were times when it felt like this is a lot, this is a lot of rehearsal time. You know, a lot of preparation time, which is demanded anytime you are putting on an event like this.

I think I've already said that she's pretty critical about how she handled the rehearsal expectations and transparency throughout the ensemble. I think I would have liked to know exactly what was going on from the get go but I don't know if she even knew... but once we went through the dress rehearsal I was like, I get it. This is big...bigger than us. ${ }^{28}$

In one of the final interviews with Women's Glee Club members, I shared that kept

hearing it is the time and lack of communication on a few things and it is not the subject matter

pushing people away. I asked if she thought that was accurate. She paused for a moment and

then responded,

No. I don't think it's the subject matter at all. One of the things I really respect that Dr. MacMullen says whenever someone might think that it's too political or something for a choir to be doing this. She says, "well we're not. We're telling stories." Right?

I don't think that really divides people. Like, "Oh no I don't really want to learn about victims of human trafficking." I don't think that's really it because we're not really pushing... we just want to inform and sort of transfer the affective part of an experience that a survivor would have to an audience. So, no, I don't think it's really an aversion to the topic at all. ${ }^{29}$

The comment immediately sparked something in my memory from an earlier interview. Another member spoke about she felt part of the success of the event was Dr. MacMullen's ability to tell a story. She made a statement that even during class when they were working on relating the music to sections of the book that Dr. MacMullen was a "gifted story teller."

\footnotetext{
${ }^{28}$ Anonymous, Interview with Women's Glee Club Member by author. Columbus, June 15, 2018.

${ }^{29}$ Anonymous. 2018. Interview with Women's Glee Club Member by author. Columbus, June 16, 2018.
} 


\section{Chapter 4}

\section{Justice in our Stories: Successful Counter Narratives}

The goal of this study is to analyze the process of choral musicking as a means of social justice within a specific community to prove the process is successful at influencing social change. Through research and presentation of information from existing scholarship, I have identified a successful approach to effective social justice through choral musicking to be the practice of counterstorying ${ }^{1}$, or rememorying. ${ }^{2}$ The same concept was present in research from various authors and given differing names, but foundational elements of both terms are based on the same process. First, the observation of an injustice in the community is identified. Then understanding of the master narrative, or counter memory, must take place as well recognizing the existing social structures and institutions that influenced the creation and continuation of this accepted social story. Finally, the creation and dissemination of a counter narrative must occur. This portion of the process is successful only when those creating the counterstory have the lived experience of this injustice and are considered the primary voices.

In chapter one, I included statements from various ethnologists, sociologists, and ethnomusicologists sharing their experience with practicing reflexive theology throughout their research process. The importance of acknowledging background information about the author and relevant discussion of how that influences the interpretation and presentation of data seems obvious and refreshing to me. Despite being a white female living and working in the central northeast region of the United States, my level of lived experience with the stigmatization and

\footnotetext{
${ }^{1}$ Julia Balén, A Queerly Joyful Noise: Choral Musicking for Social Justice (New Brunswick: Rutgers University Press, 2017).

${ }^{2}$ Gregory Barz, Singing for Life: HIV/AIDS and Music in Uganda (London: Routledge, 2014).
} 
inequity of human trafficking victims in Columbus, Ohio, is practically non-existent. However, my involvement with various social justice organizations and a local community choir for individuals in recovery from addiction does influence the focus of this research as I hope to apply its findings moving forward.

From the semi-structured interviews, I held with all current members of The Ohio State University Women's Glee Club, their collaborative pianist Casey Cook, and its director Kristina MacMullen I gained insight into the positive and negative aspects of preparing for the Concept Freedom summit. An important part of obtaining expedited IRB approval for these interviews came from my suggestion of preparing a packet of information on local counseling, therapy, and guidance services in the Columbus area in anticipation of any individuals becoming emotionally upset during the interview process. This was beneficial as it provided me more knowledge of existing services and illustrated the compassion and respect of participants and what they chose to share when we spoke. All women interviewed agreed the primary problem was the large amount of time needed for rehearsal of an event with this scale. Incorporating multi-sensory elements of staging, lighting, movement, and dance as well as other ensembles required a major time commitment that some women said would not have been as big as issue for them if it had been explained from the beginning. I expected to find that the subject matter was the problematic issue. I hypothesized that it may be viewed as too demanding and unpleasant for those in the group to engage with day after day in rehearsal or there was push back from the university or community that it was too political. That was not the case.

One of the themes to emerge from my analysis of individual stories was that of experienced sexual abuse and the emotional healing they experienced during Concept Freedom. Of the twenty women interview, four of them chose to disclose their story as a survivor of sexual 
abuse. This was not one of the scripted questions for the interview session, nor was it one I asked on the spot. Each of these young women described detailed moments of healing and those moments occurred during different periods of the musicking process. For one interviewee she found comfort in the rehearsal space of the smaller chamber choir group and recalled working on a piece with them that provided space for her to be sad for what happened. Another recalled intense feelings of empowerment during the performance as she broke through the tulle entwining her arms and had the privilege of telling another survivor's story. A third young woman explained the sense of purpose and security of identity she felt in herself following the preparation and performance. She will not pursue music as a career but realized the voice the found for advocacy through this shared process can help her continue "doing something" about human trafficking and domestic abuse in her new job at a local business following graduation. The final survivor spoke of the gratifying and healing nature of connecting with other survivors through the process and building connections that strengthened and validated her experience. ${ }^{3}$

I anticipated the findings to reflect a major increase in political activist involvement from the participants, new community initiatives that resulted from the summit, and perhaps new laws or amended policies in the area. However, of twenty participants only two qualified themselves as politically active in the community. Another sixteen said no and the remaining two responded with a moderate statement to the extent of, "Kind of, but I would like to be." When I asked Dr. MacMullen and Prof. Cook if they recalled campus or community initiatives focused on human trafficking following the Concept Freedom summit, both said no, or at least not that they were

\footnotetext{
${ }^{3}$ Anonymous, Interview with Women's Glee Club Member by author.
} 
aware of taking place. I was predicting tangible results that would prove the efficiency of choral musicking as a vehicle for social justice in the community.

As I continued to reflect on the findings, transcribe interviews, and analyze data I found a comfort level with the intangible evidence of this process. Rather than transform the audience and community through a single powerful performance, MacMullen and The Ohio State Women's Glee Club were advocates who initiated conversation. That is successful social justice. Laws are not justice, ${ }^{4}$ as introduced in the first chapter of this document, and thus, the measure of social justice cannot be law alone. The group used their position and privilege to provide a platform to tell the story of a "survivor leader" of human trafficking. ${ }^{5}$ And more importantly, the young women in the group are comfortable and confident going out into that community and speaking to the topic of human trafficking. In interview after interview, these women spoke about asking the people around them if they are aware of the implications of joking with terms like pimp and hooker. They shared about telling friends and family of their internal transformation of viewing sex trafficking survivors as the same as they are, realizing they walk next to them each day, and hugging women they met through the process. The research suggests increased levels of empathy and healing in participants, as well as a more clearly defined sense of self-identity and group identity. Choral musicking did influence social change.

I do acknowledge there are limitations of my research. First, the event took place in 2015 so memory may be affected by the amount of time that has passed. Perhaps the amount of time between the performance and study is the primary reason participants did not recall specific

\footnotetext{
${ }^{4}$ Higgins, "Hospitable Music Making: Community Music as a Site for Social Justice," in The Oxford Handbook of Social Justice in Music Education, edited by Paul Woodford (New York: Oxford University Press, 2015), 448.

${ }^{5}$ Rachel Lloyd, Girls like Us: Fighting for a world where girls are not for sale, an activist finds her calling and heals herself (New York: Harper Collins Publishers, 2011).
} 
pieces or composers. Perhaps that distance has let some of the other negative experiences of the process escape their sight. Second, participants may have felt the need to say positive things about the experience as the interviews were conducted on campus. I believe many were honest and provided a realistic view of the positive and negative experiences involved but there is a chance the location was detrimental, or at the very least, created bias. There is an obvious gender limitation. While I do stand behind my statement that in this case choral musicking lead to social change, my research only included women as participants. I did attempt to balance this by using gay men's choruses as one of the primary sources of existing scholarship in chapter two and including male performers from Gregory Barz’s research in Uganda as well.

There were also problems which arose during research. I planned to interview Jennifer Kempton to include the voice of a survivor leader in this study. I anticipated gaining additional information about the community reception of her and her business as her status as a trafficking victim was known in the area as a result of her work not only with Concept Freedom but with founding Survivor's Ink. With her untimely passing, the research also lost an important voice. I could not locate another person equally involved in the summit and the survivor community to replace her narrative so that point of view is absent from the research.

This research provides positive results found in qualitative data concerning the success of choral musicking to promote social justice. It includes Kristina MacMullen's experience of identifying a social justice issue that was important to her and the process of learning about it. Her account is one of asking others for guidance and learning from those with lived experience who best to attempt to restore equality and value. The interviews of the choral musicians involved offer individual account of change, social change through choral musicking. There are issues in every community that need to be addressed, that $10 \%$ of things, as Katrina Šilec 
references, we do not like to talk about. My hope with this study is to provide an approach for choral directors interesting in addressing one of those issues. It is not intended to be a precise protocol to be followed but more so offer the experience and process of an existing event as a starting point. The study is also intended to validate the application of choral musicking as a means of creating community, fostering personal healing, and promoting social change.

So what happens next? This work is not designed to sit on a shelf or serve as a complete study into the practice of choral musicking and social justice. There is a call and need for the kind of healing, community building, and music making choirs offer on every level, from community choir to elite professional groups. In the past year I prepared a social justice-based piece with the West Virginia University Women's Choir. During those rehearsals we of course learned notes and rhythms but we dove into the text. The Women's Choir prepared Kym Baryluk's 2012 Warrior whose text is a poem written by a survivor of domestic abuse. These young women meet twice a week for rehearsal and many do no know one another outside of that room. As we discussed text and how it would shape our artistic interpretation and performance practice, the women learned about the counter narrative provided. Some chose to share their own stories as we came close to the performance date. Others asked general questions and inquired about what services or organizations are available locally for those in need. Following the performance, multiple audience members approach me or members of the choir and thanked us for "telling their story," "singing about what it is really like," and "showing survivors are powerful.” We choral musicians can do more.

As mentioned in the introduction, my intention with this research was quite self-serving. I see a need in my immediate community related to addiction and I was not sure the best way I, a choir director, could be effective at making a difference. Through research and interviews I've 
learned two important facts: 1 . I am not alone in that feeling of desire without a clear path to action and 2. The other side of the story and path to solutions are already present in the voices of those individuals around me. I believe collaborative social justice, the truly effective kind, can evolve from choral musicking. It will look different in each case and that is part of the importance of sharing individual experiences with this process. There is a need for more scholarship. Be willing to ask questions. Find the intersections of music, social justice, and who knows what other areas in your community. Get comfortable being uncomfortable, even if only momentarily, and identify opportunities to share the counter narrative. Build community through connections with choral music and foster social change. For me, it is imperative that I do not get caught up in what success looks like and instead remember the change may be within the members of my group, as it was with The Ohio State Women's Glee Club, and not initially the community at large. As the individuals who participated in choral musicking go forth in their normal interactions, the counter narrative goes with them. So, to answer the question in my introduction, which I hear on a regular basis when I share about this research, "Do you really think music can change things?" I reply, "It already has." 


\section{Bibliography}

Ahlquist, Karen. Chorus and Community. Urbana: University of Illinois Press, 2006.

Alcoff, Linda. "The Problem of Speaking for Others.” Cultural Critique, no. 20 (1991): 5-32. https://doi.org/10.2307/1354221.

Anonymous. Interview with Women's Glee Club Member by author. Columbus, June 20, 2018.

Avery, Susan, Casey Hayes, and Cindy Bell. "Community Choirs: Expressions of Identity through Vocal Performance.” In Community Music Today. Lanham, United States: R\&L Education, 2013. http://ebookcentral.proquest.com/lib/wvu/detail.action?docID=1117171.

Bal, Mieke, Jonathan Crewe, and Leo Spitzer. Acts of Memory: Cultural Recall in the Present. Hanover, NH : Dartmouth College: University Press of New England, 1999.

Balén, Julia “Jules.” A Queerly Joyful Noise: Choral Musicking for Social Justice. New Brunswick: Rutgers University Press, 2017.

Barz, Gregory F. Singing For Life: HIV/AIDS and Music in Uganda. Routledge, 2014.

. "The Performance of HIV/AIDS in Uganda: Medical Ethnomusicology and Cultural Memory." In The Oxford Handbook of Medical Ethnomusicology, 164-84. Oxford University Press, 2008.

—. "We Are from Different Ethnic Groups but We Live Here as One Family': The Musical Performance of Community in Tanzanian Kwaya," 19-44. Chorus and Community. University of Illinois Press, 2006.

Barz, Gregory F., and Judah Cohen. The Culture of AIDS in Africa: Hope and Healing Through Music and the Arts. Oxford University Press, 2011.

Barz, Gregory F., and Timothy J. Cooley. Shadows in the Field: New Perspectives for Fieldwork in Ethnomusicology. Oxford University Press, 2008.

Bates, Vincent C. "Reaffirming Critical Theory for Social Justice in Music Education." Action, Criticism, and Theory for Music Education 15, no. 5 (2016): 1-5.

Bauman, Richard. "Verbal Art as Performance." American Anthropologist 77, no. 2 (June 1, 1975): 290-311. https://doi.org/10.1525/aa.1975.77.2.02a00030.

Bird, Frances. "Singing Out: The Function and Benefits of an LGBTQI Community Choir in New Zealand in the 2010s." International Journal of Community Music 10, no. 2 (July 2017): 193-206. https://doi.org/10.1386/ijcm.10.2.193_1. 
Bithell, Caroline. A Different Voice, A Different Song: Reclaiming Community through the Natural Voice and World Song. Oxford; Oxford University Press, 2014.

Blackford, Mansel G. Columbus, Ohio: Two Centuries of Business and Environmental Change. Columbus: Trillium, an imprint of The Ohio State University Press, 2016.

Boerger, Kristina Gisele. "Whose Music Is It, Anyway? Black Vocal Ensemble Traditions and the Feminist Choral Movement: Performance Practice as Politics.” University of Illinois at Urbana-Champaign, 2000. https://www.ideals.illinois.edu/handle/2142/85883.

Bowles, Norma, and Daniel-Raymond Nadon. Setting the Stage for Social Justice: Collaborating to Create Activist Theatre. Theater in the Americas. Carbondale: Southern Illinois University Press, 2013.

Butler, Judith. Gender Trouble: Feminism and the Subversion of Identity. Routledge Classics; Routledge Classics. New York: Routledge, 2006.

Carr, Bruce. “Ohio State University School of Music | Grove Music.” Accessed July 4, 2018. http://www.oxfordmusiconline.com/view/10.1093/gmo/9781561592630.001.0001/omo9781561592630-e-0000050073.

“CATCH Court.” Catch Court. Accessed July 5, 2018. https://www.catchcourt.org/.

Cook, Casey. Interview with Women's Glee Club collaborative pianist by author. Columbus, June 21, 2018.

Eyerman, Ron. "Music in Movement: Cultural Politics and Old and New Social Movements." Qualitative Sociology 25, no. 3 (September 1, 2002): 443-58. https://doi.org/10.1023/A:1016042215533.

Eyerman, Ron, and Andrew Jamison. "Social Movements and Cultural Transformation: Popular Music in the 1960s." Media, Culture \& Society 17, no. 3 (July 1, 1995): 449-68. https://doi.org/10.1177/016344395017003006.

Feintuch, Burt, ed. Eight Words for the Study of Expressive Culture. University of Illinois Press, 2003. http://www.jstor.org/stable/10.5406/j.ctt2ttc8f.

Gould, Elizabeth. "Social Justice in Music Education: The Problematic of Democracy." Music Education Research 9, no. 2 (July 2007): 229-40. https://doi.org/10.1080/14613800701384359.

Hadley, Susan. Feminist Perspectives in Music Therapy. Dallas, TX: Barcelona Publishers, 2014.

Harvey, Robin, Michael Smith, Nicholas Abraham, Sean Hood, and Dennis Tannenbaum. "The 
Hurricane Choir: Remote Mental Health Monitoring of Participants in a CommunityBased Intervention in the Post-Katrina Period." Journal of Health Care for the Poor and Underserved 18, no. 2 (May 1, 2007): 356-61. https://doi.org/10.1353/hpu.2007.0033.

Hayes, Casey J. "Community Music and the GLBT Chorus." International Journal of Community Music 1, no. 1 (March 2008): 63-67. https://doi.org/10.1386/ijcm.1.1.63/0.

Henderson, Shannon D., and Stan H. Hodges. "Music, Song, and the Creation of Community and Community Spirit by a Gay Subculture.” Sociological Spectrum 27 (January 1, 2007): 57-80.

Higgins, Lee. "Hospitable Music Making: Community Music as a Site for Social Justice.” In The Oxford Handbook of Social Justice in Music Education, 446-55. Oxford University Press, 2015.

Hilliard, Russell E. “A Social and Historical Perspective of the San Francisco Gay Men's Chorus.” Journal of Homosexuality 54, no. 4 (June 10, 2008): 345-61. https://doi.org/10.1080/00918360801991208.

Jorgensen, Estelle. "Intersecting Social Justices and Music Education." In The Oxford Handbook of Social Justice in Music Education, 7-28. Oxford University Press, 2015.

Kelly, Patricia, (Author). "Music Combined with Social Justice." Collected Work: Opera-Opera. 361 (2007): Swansong. Published by: Sydney, Australia: Opera-Opera, 2007. (AN: 200708070)., no. 361 (2007): 5-5.

Klein, Steven. "Columbus | Ohio, United States.” Encyclopedia Britannica. Accessed July 4, 2018. https://www.britannica.com/place/Columbus-Ohio.

Koen, Benjamin. The Oxford Handbook of Medical Ethnomusicology. Oxford University Press, 2008.

Lave, Jean, and Etienne Wenger. Situated Learning: Legitimate Peripheral Participation. Cambridge University Press, 1991.

Lawless, Elaine J. “'I Was Afraid Someone like You... an Outsider... Would Misunderstand': Negotiating Interpretive Differences between Ethnographers and Subjects." The Journal of American Folklore 105, no. 417 (1992): 302-14. https://doi.org/10.2307/541758.

Lewis, Magda. "Interrupting Patriarchy: Politics, Resistance, and Transformation in the Feminist Classroom." Harvard Educational Review 60, no. 4 (December 1, 1990): 467-89. https://doi.org/10.17763/haer.60.4.w1r67q5135585122.

Lloyd, Rachel. Girls like Us: Fighting for a World Where Girls Are Not for Sale, an Activist Finds Her Calling and Heals Herself. 1st ed. New York: HarperCollins Publishers, 2011. 
Martinez, Maria X. “The Art of Social Justice.” Social Justice 34, no. 1 (107) (2007): 5-11.

MacMullen, Kristina. Interview with Women's Glee Club director by author. Columbus, June 21, 2018.

_. "Kristina Caswell MacMullen.” mysite. Accessed July 4, 2018. https://www.kristinamacmullen.com.

—. "The Ohio State University Women's Glee Club." School of Music, March 11, 2015. https://music.osu.edu/wgc/about.

McPherson, Gary, and Graham F. Welch. The Oxford Handbook of Music Education. OUP USA, 2012.

Metzelaar, Helen. "Spiritual Singing Brings in the Money: The Fisk Jubilee Singers Tour Holland in 1877." In Chorus and Community, 165-84. University of Illinois Press, 2006.

Miles, Jennifer, and Laura Dawson. "The Art of Social Justice." Humboldt Journal of Social Relations 34 (2012): 2-8. http://www.jstor.org/stable/humjsocrel.34.2.

Mukhopadhyay, Anupa, and Ashok K. Dutt. "Population Density Gradient Changes of a Postindustrial City - Cleveland, Ohio (1860-1990).” GeoJournal 34, no. 4 (1994): 51518. http://www.jstor.org/stable/41146345.

Pettan, Svanibor, and Jeff Todd Titon. The Oxford Handbook of Applied Ethnomusicology. Oxford University Press, 2015.

Reger, Jo. "Where Are the Leaders? Music, Culture, and Contemporary Feminism." The American Behavioral Scientist; Thousand Oaks 50, no. 10 (June 2007): 1350-69. ProQuest. Web. 18 May 2018.

Schyff, Dylan van der, Andrea Schiavio, and David J. Elliott. "Critical Ontology for an Enactive Music Pedagogy." Action, Criticism \& Theory for Music Education 15, no. 5 (October 2016): 81-121. https://doi.org/10.22176/act15.5.81.

Shaw, Julia. "The Skin That We Sing: Culturally Responsive Choral Music Education." Music Educators Journal 98, no. 4 (2012): 75-81. http://www.jstor.org/stable/41692642.

Small, Christopher. Musicking: The Meanings of Performing and Listening. Middletown, United States: Wesleyan University Press, 2011. http://ebookcentral.proquest.com/lib/wvu/detail.action?docID=776766.

Stige, Brynjulf. Where Music Helps: Community Music Therapy in Action and Reflection. Ashgate Popular and Folk Music Series; Farnham, England; Ashgate, 2010.

Strachan, Jill. "The Voice Empowered: Harmonic Convergence of Music and Politics in the 
GLBT Choral Movement.” In Chorus and Community, 248-64. University of Illinois Press, 2006.

Sutton, Julie P. Music, Music Therapy and Trauma: International Perspectives. 1 online resource (272 pages) London; J. Kingsley Publishers, 2002.

Vaillancourt, Guylaine. "Music Therapy: A Community Approach to Social Justice." The Arts in Psychotherapy, Creative Arts Therapies and Social Justice, 39, no. 3 (July 1, 2012): 17378. https://doi.org/10.1016/j.aip.2011.12.011.

Veblen, Kari K., Stephen J. Messenger, Marissa Silverman, and David J. Elliott. Community Music Today. Lanham, United States: R\&L Education, 2013. http://ebookcentral.proquest.com/lib/wvu/detail.action?docID=1117171.

Wilson, Jeremy M., and Erin Dalton. "Human Trafficking in the Heartland: Variation in Law Enforcement Awareness and Response." Journal of Contemporary Criminal Justice 24, no. 3 (August 2008): 296-313. https://doi.org/10.1177/1043986208318227.

Wolfe-Hill, Nana. "Collaboration and Meaning Making in the Women's Choral Rehearsal.” In Collected Work: The Oxford Handbook of Choral Pedagogy. Series: Oxford Handbooks, Published by: New York, NY, U.S.A.: Oxford University Press, 2017. Pages: 185-203. New York: Oxford University Press, 2017.

Womack, Jennifer L. Singing for Our Lives: Exploring the Interaction of Community, Feminism and Musical Performance in the Common Woman Chorus. The University of North Carolina at Chapel Hill, 2009.

http://search.proquest.com/openview/302fe8e8d630c41b465ebb2d92629804/1?pqorigsite $=$ gscholar \&cbl $=18750 \&$ diss $=\mathrm{y}$.

Yerichuk, Deanna. "Transforming Our World Through Song." Women \& Environments International Magazine no. 72/73 (Fall/Winter 2006): 36-37. Academic Search Complete. http://search.ebscohost.com/login.aspx?direct=true \&db=a9h\&AN=24107034\&site=ehos -live. 